\title{
THE CANADian ARCTIC: The Changing SeAsCAPE OF OfFSHORE OIL AND GAS EXPLORATION ISSUES
}

\author{
WYLIE SPICER, Q.C. ${ }^{*}$ AND TANYA BATH ${ }^{* *}$
}

This article examines issues affecting the offshore oil and gas business in the Canadian Arctic. It begins by discussing the impact of international conventions and the roles of the international organizations that administer them, or have direct interests in the Arctic. It then addresses the implications of Canadian sovereignty, relevant legislation, land claim agreements with Aboriginal groups, and Aboriginal cases currently before the Supreme Court of Canada. It concludes with thoughts and speculations concerning the possible futures for offshore oil and gas development in the north.
Cet article examine les questions relatives aux pétrolières et gazières étrangères qui font des affaires dans l'Arctique canadien. L'article commence par traiter de l'impact des conventions internationales et des rôles des organisations internationales qui les gèrent ou qui ont des intérêts directs dans l'Arctique. Il aborde ensuite les implications de la souveraineté canadienne, la législation pertinente, les accords de revendications territoriales avec les groupes autochtones, ainsi que les causes autochtones qui sont actuellement devant la Cour suprême du Canada. Il se termine avec des pensées et conjectures sur les futurs éventuels du développement pétrolier et gazier dans le Grand Nord.

\section{TABLE OF CONTENTS}

I. INTRODUCTION . . . . . . . . . . . . . . . . . . . . . . . . 256

II. THE INTERNATIONAL FRAMEWORK $\ldots \ldots \ldots \ldots \ldots \ldots \ldots \ldots \ldots \ldots$

A. THE UNITED NATIONS CONVENTION

ON THE LAW OF THE SEA . . . . . . . . . . . . . . . . . . 258

B. THE INTERNATIONAL CONVENTION FOR THE

SAFETY OF LIFE AT SEA . . . . . . . . . . . . . . . . . . . . . . . . . . 262

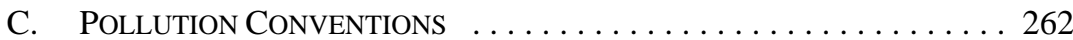

D. OTHER CONVENTIONS/AGREEMENTS

TO KeEP YOUR EYES ON . . . . . . . . . . . . . . . . . . . . . . . 262

III. The RELEVANT INTERNATIONAL ORgANIZATIONS . . . . . . . . . . . . 264

A. The Council of the EUROPEAN Union . . . . . . . . . . . . . . . . . . 264

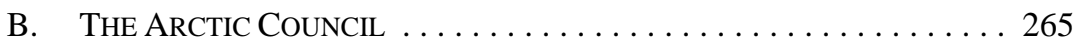

C. The International Maritime Organization $\ldots \ldots \ldots \ldots . \ldots 267$

D. The International SEABEd Authority $\ldots \ldots \ldots \ldots \ldots \ldots$

E. THE INTERNATIONAL ASSOCIATION

OF CLASSIFICATION SOCIETIES . . . . . . . . . . . . . . . . . 268

IV. CANAdian SOVEREIGNTy OVER THE ARCTIC . . . . . . . . . . . . . 268

V. CANADIAN LAW RELEVANT TO MARINE ISSUES

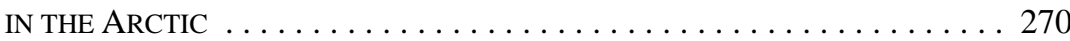

A. THE MARINE LIABILITY ACT . . . . . . . . . . . . . . . . . . . 270

B. THE CANADA SHIPPING ACT, $2001 \ldots \ldots \ldots \ldots \ldots \ldots \ldots$

C. THE OCEANS ACT . . . . . . . . . . . . . . . . . . . 272

D. The ARCTIC WATERs Pollution PreVEntion ACT . . . . . . . . . . . 274

E. The CoAsting TRAde ACt . . . . . . . . . . . . . . . . . . . 274 
VI. Oil and Gas Law ReleVAnt to the ARctic . . . . . . . . . . . . . 275

VII. THE ABORIGINAL IsSUES . . . . . . . . . . . . . . . . . . . 279

A. The INUVIALUIT FinAL AgREEMENT . . . . . . . . . . . . . . . . . 279

B. The NunAVUt LAND Claims AgREEMENT . . . . . . . . . . . . . . 280

C. THE NoRTH BAFFin REgIONAL LAND USE PLAN . . . . . . . . . . . 281

D. The Duty to Consult Aboriginal Peoples . . . . . . . . . . . 282

E. ARCtic Oil AND GAS AND Aboriginal InTERESTS . . . . . . . . . 287

F. Developments in Aboriginal Title to SeA SPACES . . . . . . 289

VIII. CONCLUSION . . . . . . . . . . . . . . . . . . . . . . . . . 293

\section{INTRODUCTION}

First explored by Indigenous peoples who have lived there for thousands of years, the Arctic is an area of continuing interest. ${ }^{1}$ Curiosity about the Arctic has always been driven by commercial interests. Centuries ago, countries began the search for a navigable Northwest Passage, beginning with the voyages of John Cabot in 1497. In 1906, the first east to west transit was completed by Roald Amundsen in the vessel Gjøa. Shortly thereafter, the Canadian government, in its first expression of concern about its sovereignty in the Arctic (a concern that very much continues today), dispatched Captain Joseph-Elzéar Bernier in the DGS Arctic. Not until 1942 was a full west to east transit completed in the St. Roch under the command of Captain Henry Larsen, who successfully sailed through the Northwest Passage from Vancouver to Halifax.

Commercial activity is no stranger to the Arctic. Whaling has been the most sustained of all activities and has been carried on since the seventeenth century. From 1610 to 1915, at least 39,000 ships went whaling in the Arctic. ${ }^{2}$ The Arctic is, for the most part, an ocean surrounded by a number of coastal states inhabited by diverse populations. The coastal states include Canada, Denmark (including Greenland and the Faroe Islands), Finland, Iceland, Norway, the Russian Federation, Sweden, and the United States. It continues to be a very busy place. $^{3}$

The oil and gas industry has frequently cast its eye towards the Arctic. Exploration commenced in the Beaufort Sea in the 1960s, with oil found in the MacKenzie Delta and at Prudhoe Bay. ${ }^{4}$ Hydrocarbon exploration has recently become of interest again. In 2008 the United States Geological Survey (USGS) concluded that perhaps up to one-third of the world's remaining recoverable reserves were located north of the Arctic Circle and that 84

The Arctic, and its fragility, is well described in the joint project of the Arctic Council and the International Science Committee: Arctic Climate Impact Assessment (Cambridge: Cambridge University Press, 2005), online: Arctic Climate Impact Assessment <http://www.acia.uaf.edu/pages/scientific.html> [ACIA]. See especially c. 1, s. 1.5 (The Arctic: geography, climate, ecology, and people).

2 The history of Arctic shipping has been well described in a paper by Professor William Barr, Arctic historian at the University of Calgary: Arctic Institute of North America, "History of Arctic Shipping Up Until 1945,” online: PAME <http://www.pame.is/amsa/amsa-background-research-documents/ images/stories/AMSA/AMSA_Background_Research_Documents/History_and_Governance_of_Ar ctic_Shipping/2-2-Early-Arctic-Marine-Transport-History.pdf>.

ACIA, supra note 1.

4 An overview of oil and gas activities in the Arctic can be found online: Arctic Monitoring and Assessement Programme <http://www.amap.no>. See especially Hein Rune Skjoldal \& Dennis Thurston, Assessment of Oil and Gas Activities in the Arctic: Process and Outline Content (January 2006). 
percent of that was located offshore. ${ }^{5}$ This is an intriguing possibility in and of itself. When combined with climate change, significant advances in vessel technology, and the decreasing safe sources of hydrocarbons worldwide, it is too good to resist.

The current search for hydrocarbons in the Arctic is the continuation of commercial enterprise in the area. At the beginning of the twenty-first century, much is transforming in the Arctic. ${ }^{6}$ Climate change is converting the face of the Arctic sea and landscapes. ${ }^{7}$ Shorter shipping routes for commercial vessels, longer seasons of safe navigation, the consequent greater accessibility to oil and gas, and a greater interest in the preservation of the environment and lifestyles of the Indigenous peoples of the Arctic have all coalesced to bring many different agendas to the fore. International organizations, nations, governmental agencies, regulatory agencies, private industries, and many others are intently pushing forward with their own agendas that will necessarily affect the search for, production, and transportation of hydrocarbons in the Arctic.

A complete appreciation of the many legal regimes relevant to the Arctic is complicated. This article provides an overview of this multifaceted area of Canada and the contiguous waters over which Canada exercises jurisdiction. The article reviews the ways in which the various parties at interest play out their roles in the Canadian Arctic. There is no other area of Canada that has so many different agendas at play. The transforming face of the Arctic environment will result in new laws, and changes in the interests and mandates of international and national agencies as their sensitivities to the Arctic develop. All of this will result in a regulatory environment that, at the present time, is difficult to foresee.

The key message is that change in the Arctic is rapid. To properly understand it, we must take a very wide view of what is relevant and we must try to look ahead. In this article, we restrict the view of relevance to issues affecting the offshore oil and gas business. We commence with a discussion of the international conventions that either have a present impact in the Arctic, or should be paid attention to for potential future application in Canada. This is followed by a discussion of the roles of a number of international organizations that are responsible for either administering international conventions or are made up of countries having direct interests in Arctic matters. With this international umbrella in place, we discuss relevant issues of Canadian sovereignty. This is followed by a review of Canadian legislation applicable to the offshore oil and gas industry in the Arctic. The role of the National Energy Board (NEB) as the principal regulator is addressed. We then outline the applicability of the three major land claim agreements with Aboriginal groups in the North as they interact with offshore oil and gas exploration in the Arctic. We consider the potential implications of Aboriginal cases currently before the Supreme Court of Canada as they may affect both the

5 USGS, “Circum-Arctic Resource Appraisal: Estimates of Undiscovered Oil and Gas North of the Arctic Circle,” Fact Sheet 2008-3049 (2008), online: USGS <http://pubs.usgs.gov/fs/2008/3049/fs20083049.pdf $>$. The USGS reported that undiscovered conventional oil and gas resources of the Arctic are estimated to be "approximately 90 billion barrels of oil, 1,669 trillion cubic feet of natural gas, and 44 billion barrels of natural gas liquids.”

6 Timo Koivurova \& Erik J. Molenaar, International Governance and Regulation of the Marine Arctic: Three Reports Prepared for the WWF International Arctic Programme (Oslo: WWF International Arctic Programme, 2009), online: WWF <http://assets.panda.org/downloads/3in1_final.pdf >.

Susan Joy Hassol, Impacts of a Warming Arctic: Arctic Climate Impact Assessment (Cambridge: Cambridge University Press, 2004), online: Arctic Climate Impact Assessment <http://www.acia.uaf. edu/pages/overview.html>. 
nature of the duty to consult, and by whom that duty is owed. The conclusion represents our thoughts and speculation concerning the possible futures for offshore oil and gas development in the north.

\section{THE INTERNATIONAL FRAMEWORK}

\section{A. The United Nations Convention on the LAW of the SEA}

\section{THE LIMITS OF CANADA AND CANADIAN WATER}

UNCLOS is an international treaty ratified by 158 countries, including all of the countries that border on the Arctic Ocean, with the exception of the U.S. Canada's ratification was effective on 7 November 2003.

UNCLOS contains many articles that can have an effect on offshore activities. As noted in Offshore Hydrocarbon: Current Policy Context in the Marine Arctic, ${ }^{9}$ numerous articles in Part XII of UNCLOS are relevant:

- Article 81 - granting coastal states "the exclusive right to authorize and regulate drilling on the continental shelf for all purposes";

- $\quad$ Article 134 - regulating offshore hydrocarbon activity in the area and requiring that such activities must be in accordance with the relevant provisions of UNCLOS;

- $\quad$ Article 194 - requiring coastal states to prevent, reduce, and control marine pollution that may arise out of offshore oil and gas activities;

- Article 196 - requiring coastal states to ensure that technology in offshore activities does not result in pollution;

- $\quad$ Article 204 - requiring coastal states to keep under surveillance the effects of activities permitted in the offshore area; and

- $\quad$ Article 235 — providing for compensation for damage caused by pollution. ${ }^{10}$

One important function of UNCLOS is to set out the regime of maritime rights for coastal states. ${ }^{11}$ This scheme has been adopted in Canada through the Oceans Act, ${ }^{12}$ which, in summary, provides as follows: 
- $\quad$ Section 5 sets out the process for determining baselines. Baselines smooth out coastlines by traversing straight across minor indentations and enclosing historic bays and other waters to which a coastal state has historic claims. Marine areas that are landward of the baselines are defined as internal waters. Baselines are defined by regulation. ${ }^{13}$

- $\quad$ Section 7 describes the internal waters and territorial sea as being a "part of Canada." Canadian federal law therefore applies in the internal waters and territorial sea in the same way that it applies onshore. International law recognizes the right of innocent passage in the territorial sea but not in internal waters.

- $\quad$ Section 10 defines the contiguous zone as being between 12 and 24 nautical miles from the baselines. Canada's legislative powers drop off considerably in this area.

- Section 11 provides that persons in the contiguous zone for whom reasonable grounds exist for fearing that they are likely to commit violations of Canada's customs, fiscal, immigration, or sanitary laws may be refused entry into Canada.

- $\quad$ Section 13 defines the "exclusive economic zone” as being between 12 and 200 nautical miles from the baselines. Within this area Canada has certain sovereign rights with regard to economic exploitation including, by ss. 14(b)(iii) and 14(c), the sovereign right to protect and preserve the marine environment in the exclusive economic zone.

- $\quad$ Section 17 defines the continental shelf of Canada in a way that has the potential to extend it beyond the exclusive economic zone depending on the "submerged prolongation of the land mass of Canada."

- $\quad$ Section 18 confirms that "Canada has sovereign rights over the continental shelf of Canada for the purpose of exploring it and exploiting the mineral and other nonliving natural resources of the seabed and subsoil of the continental shelf of Canada.” These rights are derived from art. 77 of UNCLOS. ${ }^{14}$

Determining whether or not any area forms part of the continental shelf of Canada beyond the exclusive economic zone involves analysis by the Commission on the Limits of the Continental Shelf (CLCS) as set out in Annex II of UNCLOS. ${ }^{15}$ Article 4 of this Annex requires countries to submit their claims to the CLCS within ten years from the date of their country's ratification. Canada must submit its evidence by 7 December 2013. The U.S. is not a party to UNCLOS. ${ }^{16}$ The CLCS will review the submission of Canada, then make

Territorial Sea Geographical Coordinates Order, C.R.C., c. 1550.

Supra note 12.

Supra note 8.

In "Filling an Arctic Gap: Legal and Regulatory Possibilities for Canadian-U.S. Cooperation in the Beaufort Sea” (2009) 34 Vt. L. Rev. 57 at 116, Betsy Baker points out various provisions of UNCLOS that are particularly apposite to Canada-U.S. co-operation:

Article 194(5), on protecting fragile ecosystems/endangered species habitats; Article 197, on cooperation for protection and preservation of the marine environment on a global or regional basis; Article 234, on ice-covered areas; Article 199, on contingency plans against pollution; Article 200, on studies, research programmes and exchange of information and data; Article 
recommendations regarding the outer limit of the continental shelf in accordance with its own guidelines. The final determination of the continental shelf is the right of Canada, it being the only coastal state that can establish the limits of its own continental shelf.

\section{UNCLOS: ARTICLE 82 - OFFSHORE CONTINENTAL SHELF ROYALTY PAYMENTS}

Article 82 of UNCLOS is relevant to the offshore oil and gas industry. The International Seabed Authority (ISA), which regulates the seabed pursuant to s. 4 of UNCLOS, has recently published two studies concerning issues associated with the implementation of art. 82 of UNCLOS. ${ }^{17}$

Article 82 affects coastal states that have submitted a territorial claim to the portion of the continental shelf that extends beyond the Convention-mandated 200 nautical mile limit. This area is known as the outer continental shelf (OCS). Article 82 obliges coastal states to pay what is essentially an international royalty through the ISA for the exploitation of the nonliving resources within their respective OCS. Canada has laid claim to the OCS extending into both the Arctic and Atlantic Oceans. The Canada-Newfoundland and Labrador Offshore Petroleum Board currently has exploration licences in areas outside the 200 nautical mile limit in the northwest Atlantic. ${ }^{18}$

The ISA is authorized by UNCLOS to organize and control activity in the International Seabed Area (the Area), which comprises those sections of ocean floor that are not part of a territorial claim by a state. At international law, the Area and its mineral resources are considered to be part of the "common heritage of mankind."19 Because OCS claims will decrease the size of the Area and, concomitantly, the amount of resources in the Area, art. 82 was conceived as a compromise between the OCS interests of coastal states and those of landlocked and developing states that are net importers of mineral resources. The royalties collected from coastal states by the ISA in return for the exploitation of non-living resources in the OCS are to be disbursed to all Convention parties on the basis of "equitable sharing criteria, taking into account the interest and needs of developing States, particularly the least developed and the land-locked among them." ${ }^{20}$ The ISA does not receive the benefit of OCS royalties, but is simply the entity responsible for their collection and distribution.

Article 82 creates a three-stage process. During the offshore exploration and preproduction phase, no royalties are required. Once production commences, there is a five-year royalty-free grace period. Royalties are then triggered in the sixth year of production. Once

204, on monitoring of the risks or effects of pollution; and Article 206, on assessment of potential effects of activities on the marine environment.

ISA, Issues Associated with the Implementation of Article 82 of the United Nations Convention on the Law of the Sea, Technical Study No. 4 (Kingston, Jamaica: ISA, 2009), online: ISA <http://www.isa.org. jm/files/documents/EN/Pubs/Article82.pdf> [ISA Study No. 4]; ISA, Non-living Resources of the Continental Shelf Beyond 200 Nautical Miles: Speculations on the Implementation of Article 82 of the United Nations Convention on the Law of the Sea, Technical Study No. 5 (Kingston, Jamaica: ISA, 2010), online: ISA < http://www.isa.org.jm/files/documents/EN/Pubs/TechStudy5.pdf> [ISA Study No. 5].

ISA Study No. 4, ibid. at 3, Figure 1 at 4.

UNCLOS, supra note 8, art. 136.

Ibid., art. 82. 
triggered, art. 82 will require an annual payment or contribution in kind at an initial rate of 1 percent on the value or volume of all production, increasing thereafter by 1 percent annually until the rate reaches a maximum of 7 percent in the twelfth year of production. Resources that are used in connection with the exploitation are not considered to be part of the production and are exempt from the royalty calculation. ${ }^{21}$

ISA Study No. 4 examines and highlights many important issues relating to the ISA, landlocked and developing states, and OCS status. OCS production could begin as early as 2015. As noted in that study:

\begin{abstract}
Although Article 82 has been dormant since the adoption of the Convention, there are coastal States, in particular in Canada (which is a State Party to the Convention) and the United States (which is not yet), that have granted prospecting and/or exploration licences or leases on their OCS. Typically, offshore petroleum and mineral development operates on a timeframe that can span decades. Today's prospecting and exploration licence may become a development and production licence within perhaps 10-20 years of initial activity. However, it is possible that Article 82 revenues will come due as soon as 2015. Either way, Article 82 will soon awaken. ${ }^{22}$
\end{abstract}

In this regard, ISA Study No. 4 notes that the commercial viability of offshore drilling in the OCS must be examined with the art. 82 royalty regime in mind. The art. 82 royalty obligation should also be considered at the earliest stages, including the granting of exploration licences, and even the planning of domestic royalty regimes:

At this time it appears that very few OCS States are aware of the significance of Article 82. OCS States need to become aware of the implications of Article 82 when defining the outer limits of the continental shelves and proceeding to offshore exploration and development. ${ }^{23}$

ISA Study No. 5 also concerns art. 82. It refers to Canada as "a good example of a very wide margin coastal State with a continental shelf already featuring intense exploitation of oil and gas at a range of water depths." ${ }^{24}$ It is noted that Canada has two areas where potential continental shelf exploration beyond 200 miles is likely: off the east coast of Canada and in the Arctic Ocean. ${ }^{25}$ However, this study seems to suggest that there is little potential beyond 200 miles in the Arctic Ocean:

[M] ost of the offshore areas with the highest probability for the discovery of hydrocarbons (oil or natural gas) are well within the national jurisdiction of Arctic Ocean littoral States and that the areas beyond 200-n. miles in the Arctic Ocean Basin are not seen as having a high or even middling probability for the recovery of hydrocarbon resources. ${ }^{26}$

The issue most likely to become contentious is whether the federal government will seek to offset its royalty obligations through its taxation powers and, if so, what form that taxation

Ibid., art. 82(2).

Supra note 17 at xi.

Ibid. at 47.

Supra note 17 at 49.

Ibid.

Ted L. McDorman, "The Continental Shelf Beyond 200 NM: Law and Politics in the Arctic Ocean” (2009) 18 J. Transnat'l L. \& Policy 155 at 157, cited in ISA Study No. 5, ibid. at 20. 
will take. To date, no tax has been imposed. A conceivable scenario, however, is a tax imposed directly on producing oil companies. Such a measure would surely give rise to federal-provincial rancour and would undoubtedly affect how companies interested in OCS production will act.

\section{B. THE INTERNATIONAL CONVENTION FOR THE SAFETY OF LIFE AT SEA}

The sinking of the Titanic in 1912 gave a jumpstart to the development of an international regime to ensure marine safety. ${ }^{28}$

SOLAS has had a number of iterations, now represented by its 1974 version. Canada is a contracting state to SOLAS and is required to ensure that ships flying the Canadian flag comply with the various requirements of SOLAS. A number of the regulations and requirements of SOLAS have been enacted in Canada through regulations made pursuant to the Canada Shipping Act, 2001. ${ }^{29}$

\section{Pollution Conventions}

There are many international conventions relating to pollution and discharge from ships. Insofar as Canada is concerned, these conventions are given effect by the CSA and the Marine Liability $A c t,{ }^{30}$ which share responsibility for issues arising out of oil pollution matters. As is discussed below, the Arctic Waters Pollution Prevention Act ${ }^{31}$ has application also.

\section{OTHER CONVENTIONS/AgREEMENTS TO KEEP YOUR EYES ON}

\section{AGREEMENT BETWEEN THE GOVERNMENT OF CANADA AND THE GOVERNMENT OF THE KINGDOM OF DENMARK RELATING TO THE DELIMITATION OF THE CONTINENTAL SHELF BETWEEN GREENLAND AND CANADA ${ }^{32}$}

This agreement sets out the dividing line "between Greenland and the Canadian Arctic Islands, established for the purpose of each Party's exploration and exploitation of the natural resources of that part of the continental shelf." ${ }^{33}$ Article V provides that if a petroleum field extends across the dividing line, the parties shall seek to reach an agreement regarding its exploitation. $^{34}$

1 November 1974, 1184 U.N.T.S. 2, Can. T.S. 1980 No. 45 (entered into force 25 May 1980) [SOLAS]. A good overview of the current governance of shipping in the Arctic is provided in David L. VanderZwaag et al., Governance of Arctic Marine Shipping (Halifax: Dalhousie University Marine \& Environmental Law Institute, 2008), online: Arctic Portal < http://web.arcticportal.org/uploads/bC/JU/ bCJUaKAo52Xtt HDZ359QNA/5.novAMSA-Governance-of-Arctic-Marine-Shipping-Final-Report-1Aug.pdf $>$.

S.C. 2001, c. $26[C S A]$.

S.C. 2001 , c. $6[M L A]$.

R.S.C. 1985 , c. A-12 [AWPPA].

17 December 1973, 950 U.N.T.S. 147, Can. T.S. 1974 No. 9 (entered into force 13 March 1974, as amended by Exchange of Notes, 16 December 2009).

Ibid., art. I.

Ibid. 


\section{AGREEMENT BETWEEN THE GOVERNMENT OF CANADA AND THE GOVERNMENT OF THE KINGDOM OF DENMARK FOR COOPERATION RELATING TO THE MARINE ENVIRONMENT ${ }^{35}$}

This agreement between Canada and Denmark (the two countries that share the longest maritime boundary in the world) was entered into in 1983 and amended by an Exchange of Notes in $1991 .^{36}$ Article $\mathrm{V}$ of that agreement is relevant to the offshore:

The Parties shall take measures to ensure that installations engaged in exploration for or exploitation of the natural resources of the seabed and subsoil in their respective areas of responsibilities are designed, constructed, placed, equipped, marked, operated and maintained in such a manner that the risk of pollution of the marine environment is minimized. ${ }^{37}$

The relevant lands are those that lie between Greenland and Canada. ${ }^{38}$ There is considerable activity offshore of Greenland where, at present, 13 licences have been granted. The Scottish oil company, Cairn Energy PLC (Cairn), has acquired a leading acreage position offshore Greenland, with interests in eight hydrocarbon exploration licences. The semi-submersible Stena Don will begin drilling as part of Cairn's exploration program offshore western Greenland in the summer of $2010 .{ }^{39}$ What is of interest here is that these offshore prospects are off the west coast of Greenland proximate to Baffin Island. The Greenland oil company, Nunaoil, is currently involved in a number of exploration licences offshore western Greenland. ${ }^{40}$

\section{OSPAR CONVENTION FOR THE PROTECTION OF THE MARINE ENVIRONMENT OF THE NORTH-EAST ATLANTIC ${ }^{41}$}

OSPAR is the Convention by which 15 governments of western coastal Europe, along with the European Community, co-operate to protect the marine environment of the northeast Atlantic. One of the areas covered by the Convention is the Arctic waters relevant to the member states, which constitutes approximately 40 percent of the OSPAR maritime area. ${ }^{42}$ The OSPAR Commission, set up to administer the Convention, recognizes that petroleum production is one of the most important human activities in the Arctic area. ${ }^{43}$ The concept of

26 August 1983, 1348 U.N.T.S. 113, Can. T.S. 1983 No. 19 (entered into force 26 August 1983).

7 October 1991, 1853 U.N.T.S. 447, Can. T.S. 1991 No. 35.

Supra note 35.

As recently as 8 February 2010, a Nunavut online newspaper ran an article indicating that Nunavut envies the way in which Greenland has moved ahead with its oil and gas activities: Jim Bell, "Nunavut officials envy Greenland oil-gas model” Nunatsiaq Online (8 February 2010), online: Nunatsiaq Online <http://www.nunatsiaqonline.ca/stories/articles/8769_nunavut_officials_envy_greenland_oilgas_model>. Oil and gas exploration in Nunavut ceased in 1985.

39 For details concerning this activity, see “Greenland Interests,” online: Cairn <http://www.cairnenergy. com/operations/greenland/>.

40 Maps for these licences can be seen online: Nunaoil <http://www.nunaoil.gl/Efterforskningslicenser/ tabid/91/Default.aspx>. Nunaoil's presentation to the EU's Arctic Communication in Brussels on 29 October 2009 at a seminar on the EU in the Arctic is informative: "Greenland Representation to the EU, Brussels,” online: Greenland Home Rule Government <http://eu.nanoq.gl/>.

4122 September 1992, 2354 U.N.T.S. 67, U.K.T.S. 1999 No. 14 (entered into force 25 March 1998).

42 OSPAR Commission, "Region I - Arctic Waters," online: OSPAR Commission <http://www.ospar. org/content/content.asp?menu=00420211000000_000000_000000>.

43 Annex III to the Convention is concerned with the "Prevention and Elimination of Pollution from Offshore Sources.” 
"marine protected areas" is one of the articulated mandates of the OSPAR Commission. ${ }^{44}$ This concept has been statutorily recognized in Canada in the Oceans Act, which will be discussed below. ${ }^{45}$

\section{AGREEMENT ON THE CONSERVATION OF POLAR BEARS ${ }^{46}$}

This 1973 agreement between the governments of Canada, Denmark, Norway, the former USSR, and the U.S. recognizes the responsibility for coordination of actions to protect polar bears and commits all signatories to the protection of the ecosystems and the migration corridors of polar bears. ${ }^{47}$

The foregoing international conventions are the footprint of world opinion. They represent an international consensus.

\section{THE RELEVANT INTERNATIONAL ORGANIZATIONS}

\section{A. The Council OF THE EUROPEAN UNiON ${ }^{48}$}

The Council of the European Union is the principal decision-making institution of the European Union (EU). It is composed of ministers from each EU state.

Since some EU states border on the Arctic, it is worthwhile paying attention to their work. On 27 November 2009, the Council reached certain conclusions concerning the Arctic. ${ }^{49}$ It may be a first step towards an EU Arctic policy. The Council approved the three main policy objectives of the EU Commission in connection with the Arctic.

- $\quad$ Protecting and preserving the Arctic in unison with its population;

- $\quad$ Promoting sustainable use of natural resources;

- Contributing to enhanced governance in the Arctic through implementation of relevant agreements, frameworks and arrangements, and their further development. ${ }^{50}$

See Erik J. Molenaar \& Alex G. Oude Elferink, “Marine protected areas in areas beyond national jurisidiction: The pioneering efforts under the OSPAR Convention” (2009) 5 Utrecht L. Rev. 5. In 2003, the Commission recommended a network of marine-protected areas, which was accepted by the OSPAR Commission. In 2006 the Commission published Guidance on Developing an Ecologically Coherent Network of OSPAR Marine Protected Areas, Ref. No. 2006-3, online: OSPAR Commission $<$ http://www.ospar.org/documents/dbase/decrecs/Agreements/06-03e_guidance\%20ecol\%20coherence \%20mpa\%20network.doc> [OSPAR Guidance].

$45 \quad$ Supra note 12, s. 35.

4615 November 1973, Can. T.S. 1976 No. 24, 13 I.L.M. 13 (entered into force 26 May 1976).

47 There is also a polar bear management agreement in place for the southern Beaufort Sea: see C.D. Brower et al., "The Polar Bear Management Agreement for the Southern Beaufort Sea: An Evaluation of the First Ten Years of a Unique Conservation Agreement” (2002) 55 Arctic 362.

48 Online: Council of the European Union <http://www.consilium.europa.eu/showPage.aspx?id=\&lang $=\mathrm{en}>$.

49 EC, Council of the European Union, Draft Council conclusions on Arctic issues, Doc. No. 16857/09 (Brussels: Council of the European Union, 2009), online: Council of the European Union <http:// register.consilium.europa.eu/pdf/en/09/st16/st16857.en09.pdf>. Ibid. at 3. 


\section{B. The Arctic CounciL ${ }^{51}$}

The Arctic Council is a very important player in considering issues related to the Arctic. It was established in 1996 as a high level inter-governmental forum to provide a means for promoting co-operation, coordination, and interaction among the Arctic state. The Council is composed of the countries bordering on the Arctic Ocean. The Council also created "permanent participants" in order to ensure the proper representation of Arctic Indigenous representatives. These are the Aleut International Association, the Arctic Athabascan Council, the Gwich'in Council International, the Inuit Circumpolar Council, the Saami Council, and the Russian Association of Indigenous People of the North. The Council has created working groups, which include the Arctic Contaminants Action Programme; Arctic Monitoring and Assessment Programme (AMAP); Conservation of Arctic Flora and Fauna; Emergency Prevention, Preparedness and Response; Protection of the Arctic Marine Environment (PAME); and Sustainable Development Working Group.

The Arctic Council has published many documents that are relevant for consideration in offshore development. Five recent publications are noteworthy:

\section{GUIDELINES FOR THE TRANSFER OF REFINED OIL AND OIL PRODUCTS IN ARCTIC WATERS (TROOP) ${ }^{52}$}

These guidelines, published in November 2004, “are written for vessels that may be supplying Arctic communities, industries, and other vessels working in the Arctic. The aim of these guidelines is to prevent cargo/fuel oil spillage, and the resulting environmental damage, during transfer between any two vessels or between a vessel and shore facility, in either direction."53

\section{THE ARCTIC MARINE SHIPPING ASSESSMENT 2009 REPORT ${ }^{54}$}

This very thorough report was predicated on the Council's view that " $[t]$ he Arctic is undergoing extraordinary transformations early in the 21st century. Natural resource development, governance challenges, climate change and marine infrastructure issues are influencing current and future marine uses of the Arctic." 55 AMSA makes a number of findings, including one that is particularly relevant to offshore oil and gas:

Arctic natural resource development (hydrocarbons, hard minerals and fisheries) and regional trade are the key drivers of future Arctic marine activity. However, there are many other factors and uncertainties of importance including governance, Arctic state cooperation, oil prices, changes in global trade, climate change

51 Online: Arctic Council <http://www.arctic-council.org>.

52 Arctic Council, PAME, Guidelines for Transfer of Refined Oil and Oil Products in Arctic Waters (TROOP) (Arkureyri, Iceland: PAME, 2004), online: PAME < http://old.pame.is/sidur/uploads/TROOP \%20-\%20English\%202.pdf>.

$53 \quad$ Ibid. at 3.

54 Arctic Council, PAME, Arctic Marine Shipping Assessment 2009 Report (Arkureyri, Iceland: PAME, 2009), online: PAME < www.pame.is/images/stories/PDF_Files/AMSA_2009_Report_2nd_print.pdf > [AMSA].

$55 \quad$ Ibid. at 2 . 
variability, new resource discoveries, marine insurance industry roles, multiple use conflicts and Arctic marine technologies. $^{56}$

\section{THE ARCTIC OFFSHORE OIL AND GAS GUIDELINES $2009^{57}$}

The Arctic Offshore Oil and Gas Guidelines 2009 were first developed by the Arctic Council in 1997 and have since been updated and improved. The guidelines recognize that

a number of legal instruments related to offshore oil and gas activities exist, e.g. United Nations Convention on Law of the Sea; the International Convention for the Prevention of Pollution from Ships (MARPOL 73/78); The London Convention 1972; and regional Conventions such as OSPAR. Arctic petroleum activities must be conducted in compliance with applicable international law. ${ }^{58}$

The purpose of the guidelines is expressed as "intended to be of use to the Arctic nations for offshore oil and gas activities during planning, exploration, development, production and decommissioning." 59

These guidelines describe the environmental assessment process currently in effect for Canadian offshore oil and gas activities and note the impact of the Inuvialuit settlement region and the Nunavut settlement area. ${ }^{60}$

\section{ARCTIC CLIMATE IMPACT ASSESSMENT}

This was a joint project of the Arctic Council and the International Arctic Science Committee intended to evaluate and synthesize knowledge on climate variability, climate change, and increased ultraviolet radiation and their consequences. The ACIA overview report contains a number of key findings, including that animal species, diversity, ranges, and distributions will change; reduced sea ice is very likely to increase marine transport and access to resources; and Indigenous communities are facing major economic and cultural impacts. $^{61}$

Ibid. at 5 .

Arctic Council, PAME, Arctic Offshore Oil and Gas Guidelines 2009 (Arkureyri, Iceland: PAME, 2009), online: PAME <http://www.pame.is/images/stories/FrontPage/Arctic-Guidelines-2009-13thMar2009.pdf>.

Ibid. at 3.

Ibid. at 4.

Ibid. at 84, which notes: "Efforts are underway to design a pilot, multistakeholder regional environmental assessment process for the Beaufort Basin. This study is being considered in anticipation of renewed investment in hydrocarbon exploration in the Beaufort over the next decade and is expected to inform and simplify downstream project-level assessments and regulatory decision.”

Supra note 1. See also Timo Koivurova, "Governance of protected areas in the Arctic" (2009) 5 Utrecht L. Rev. 44. 


\section{ARCTIC POLLUTION $2009^{62}$}

This 2009 report is useful to understand the many ways in which pollutants can affect the Arctic. It makes clear that the Arctic is not a "closed region" and that what occurs there may have its origin a great distance away. ${ }^{63}$

\section{THE INTERNATIONAL MARITIME ORgANIZATION}

The International Maritime Organization (IMO) is the lead agency of the United Nations responsible for issues related to the global maritime industry. In addition to playing a key role in the development of SOLAS and its many iterations, the IMO was at the helm of an international effort to agree upon an international convention concerning offshore drilling units. The Code for the Construction and Equipment of Mobile Offshore Drilling Units, 1989, commonly referred to as the MODU Code ${ }^{64}$ was completed by the IMO in 1989 and, while it proposes a very broad international framework for offshore matters, no international convention has been forthcoming. At its meetings in May and June 2009, the Maritime Safety Committee of the IMO approved a draft MODU Code that revised and updated the 1989 version and will be submitted to the IMO Assembly for adoption. ${ }^{65}$ The new MODU Code is described as providing

an international standard for mobile offshore drilling units of new construction, to facilitate the international movement and operation of these units and ensure a level of safety equivalent to that required by the SOLAS Convention and the 1988 Protocol to the Load Lines Convention for conventional ships engaged on international voyages. $^{66}$

In 2002, the IMO approved Guidelines for Ships Operating in Arctic Ice-Covered Waters. ${ }^{67}$ These guidelines were communicated to ship owners and other parties operating vessels in the Arctic. They relate to vessels operating in Arctic ice-covered waters while engaged in international voyages. The guidelines are an active part of the international attention of the shipping community currently focused on the Arctic. ${ }^{68}$ It is worth noting how quickly things are moving internationally. The IMO General Assembly, on 2 December 2009, adopted a resolution intended to make the guidelines mandatory "for ships constructed on or after 1 January 2011” and those constructed before that date "as far as is reasonable and

Arctic Council, AMAP, Arctic Pollution 2009 (Oslo: AMAP, 2009), online: AMAP <http://amap.no/ documents/index.cfm?action=getfile\&dirsub=\&filename=SOAER\%5F2009.pdf\&sort=default>. Ibid. at 18.

IMO, Code for the Construction and Equipment of Mobile Offshore Drilling Units, 1989, IMO Res. A.649(16) (19 October 1989) [MODU Code].

IMO, "Maritime Safety Committee (MSC), 86th session: 27 May - 5 June 2009," online: IMO $<$ http://www.imo.org/newsroom/mainframe.asp?topic_id=110\&doc_id=10620>.

Ibid.

IMO, Guidelines for Ships Operating in Arctic Ice-Covered Waters, MSC/Circ.1056 (23 December 2002), online: IMO <http://www.imo.org/includes/blastDataOnly.asp/data_id\%3D6629/1056-MEPCCirc399.pdf>.

Also relevant are the activities of the IMO in connection with ensuring the safe return to port of passenger ships following a casualty, addressed by the IMO Marine Safety Committee in Performance Standards for the Systems and Services to Remain Operational on Passenger Ships for Safe Return to Port and Orderly Evacuation and Abandonment After a Casualty, MSC.1/Circ.1214 (15 December 2006), online: IMO <http://www.imo.org/includes/blastDataOnly.asp/data_id\%3D16745/1214.pdf>. This has been followed up by changes to SOLAS implementation of regulations concerning safe return to port. 
practicable.”69 This has been quickly followed up by the IMO Sub-Committee on Ship Design and Equipment at their meetings in February 2010, which established a correspondence group to further develop an international code of safety for ships operating in polar waters. ${ }^{70}$ These developments will certainly have an impact on vessels operating in the Canadian Arctic.

\section{THE INTERNATIONAL SEABED AUTHORITY}

The ISA is set up pursuant to art. 156 of UNCLOS and is in charge of organizing and controlling activities in the International Seabed Area (defined in UNCLOS as "the seabed and ocean floor and subsoil thereof, beyond the limits of national jurisdiction" ${ }^{\text {"71 }}$ ) as discussed above in relation to art. 82 of UNCLOS and the potential for offshore continental shelf royalty payments.

\section{E. THE INTERNATIONAL ASSOCIATION OF CLASSIFICATION SOCIETIES}

This is an agglomeration of classification societies such as Det Norske Veritas (DNV) and the American Bureau of Shipping (ABS). These organizations, in conjunction with insurance interests and vessel owners and operators, regulate the construction and periodic surveys of ships to ensure compliance with safe standards. DNV has a series of rules related to ship operation in cold climates. ${ }^{72}$ ABS has published technical papers addressing the issue of winterization guidelines operating in Arctic waters. ${ }^{73}$

\section{Canadian Sovereignty Over the Arctic}

In the section dealing with $U N C L O S$, above, we have already described the nature of the various interests accorded to a coastal state depending on the proximity of the area to the coastal state. The discussion in this section focuses on boundary issues involving the Arctic between Canada and other nations. These issues are increasingly important as climate change changes the face of the Arctic.

Speaking in Iqaluit on 12 August 2006, Prime Minister Stephen Harper stated Canada’s position: guidelines now encompass the Antarctic as well.

IMO, “Sub-Committee on Ship Design and Equipment(DE), 53rd session: 22-26 February 2010," online: IMO <http://www.imo.org/newsroom/mainframe.asp?topic_id=107\&doc_id=11897>.

Supra note 8, Preamble.

See e.g. DNV Maritime, Ship operation in cold climates (Høvik, Norway: DNV Maritime, 2008), online: DNV < http://www.dnv.com/binaries/Ship\%20operation\%20in\%20cold\%20climates_tcm4-295010.pdf>. See e.g. Robert Conachey et al., "Winterization Guidelines for Vessels Operating in Arctic Waters," ABS Technical Paper 2007 (Paper presented at the Risk Management in Ice Navigation Seminar, London, 25-26 January 2007), online: ABS <http://www.eagle.org/eagleExternalPortalWEB/Show Property/BEA\%20Repository/References/Technical\%20Papers/2007/WinterizationGuidelines>. 
And I am here today to make it absolutely clear there is no question about Canada's Arctic border. It extends from the northern tip of Labrador all the way up the East coast of Ellesmere Island to Alert. Then it traces the western perimeter of the Queen Elizabeth Islands down to the Beaufort Sea. From there it hugs the coasts of the Northwest Territories and Yukon to the Canada-U.S. border at Alaska. All along the border, our jurisdiction extends outward 200 miles into the surrounding sea, just as it does along our Atlantic and Pacific coastlines. $^{74}$

There are two issues. One is disagreement as to sovereign rights per se and, second, disagreement as to the extent of Canada's sovereign rights involving passage through the waters of the Canadian Arctic.

On the issue of sovereign rights per se, there is an area of the Beaufort Sea over which both Canada and the U.S. claim sovereignty. ${ }^{75}$ The area in question is approximately 6,250 square nautical miles. ${ }^{76}$ There are two Canadian issued exploration licences in this disputed area that are currently under work prohibition orders in accordance with s. 12(1)(a) of the Canada Petroleum Resources Act. ${ }^{77}$ These are EL317 and EL329, issued respectively to Talisman Energy and BP Canada Energy. ${ }^{78}$ The Canadian and American icebreakers CCGS Louis St. Laurent and USC GC Hely have been mapping the bottom of the Arctic Ocean in order to make submissions to the ISA concerning the extent of the continental shelf. In 2010 these icebreakers, for the first time, are venturing into the area where these two exploration licences are situated.

On the second issue of the extent of sovereign rights, there is a difference of opinion between Canada and the U.S. as to the nature of the sovereign rights claimed by Canada in the Northwest Passage. The position taken by Prime Minister Harper is consistent with the position that virtually all of the waters of the Northwest Passage are landward of the baselines and would therefore constitute internal waters of Canada. The U.S. is of the view that since this is a strait used for international navigation, it is not part of Canada's internal waters. ${ }^{79}$ A potential quarrel, perhaps, but unlikely. Article 234 of UNCLOS gives a coastal state a number of rights with respect to ice-covered areas regardless of any territorially based claim of sovereignty:

Coastal States have the right to adopt and enforce non-discriminatory laws and regulations for the prevention, reduction and control of marine pollution from vessels in ice-covered areas within the limits of the exclusive economic zone, where particularly severe climatic conditions in the presence of ice covering such areas for

74 Stephen Harper, "Securing Canadian sovereignty in the Arctic,” online: Prime Minister of Canada $<$ http://pm.gc.ca/eng/media.asp?id=1275>.

75 See map at Northern Oil and Gas Branch, “Oil \& Gas Dispositions: Beaufort Sea \& MacKenzie Delta,” online: Indian and Northern Affairs Canada <http://www.ainc-inac.gc.ca/nth/og/le/mp/bsmd/beau_ pg.pdf $>$.

76 David H. Gray, “Canada’s Unresolved Maritime Boundaries” IBRU Boundary and Security Bulletin 5:3 (Autumn 1997) 61 at 64, online: International Boundaries Research Unit <http://www.dur.ac.uk/ resources/ibru/publications/full/bsb5-3_gray.pdf>.

$77 \quad$ R.S.C. 1985 (2d Supp.), c. 36 [CPRA].

78 Indian and Northern Affairs Canada, Northern Oil and Gas Annual Report 2008 (Ottawa: Public Works and Government Services Canada, 2009) at 16, online: Indian and Northern Affairs Canada <http:// www.ainc-inac.gc.ca/nth/og/pubs/ann/ann2008/ann2008-eng.pdf $>$. See also Ted L. McDorman, Salt Water Neighbors: International Ocean Law Relations Between the United States and Canada (Oxford: Oxford University Press, 2009) at 187. 
most of the year create obstructions or exceptional hazards to navigation, and pollution of the marine environment could cause major harm to or irreversible disturbance of the ecological balance. Such laws and regulations shall have due regard to navigation and the protection and preservation of the marine environment based on the best available scientific evidence. ${ }^{80}$

Insofar as the Northwest Passage is concerned, it has been suggested that the effect of art. 234 is to trump the free right of navigation in an international strait articulated in art. $233 .{ }^{81}$

It may be worthy of note, however, that in November of 2008 the European Commission - the executive body of the EU — issued a communication to the European Parliament concerning the EU and the Arctic region. While recognizing that there were "different interpretations of the conditions for passage of ships in some Arctic waters, especially in the Northwest Passage," 82 the Commission urged its members to "defend the principle of freedom of navigation and the right of innocent passage in the newly opened routes and areas." ${ }^{83}$ This statement leans toward the position taken by the U.S. that the Northwest Passage is an international strait. A reduction of ice in the Northwest Passage due to climate change has obviously drawn the attention of the EU to this issue. ${ }^{84}$

\section{Canadian Law ReleVant to Marine Issues in the ARCTIC}

The preceding discussions outlining the roles of international conventions and international organizations are particularly relevant to the body of Canadian law governing oil and gas related marine issues in the Arctic. In this Part we will focus on Canadian legislation that deals with such issues.

\section{A. THE MARINE LIABILITY ACT}

Several articles of the International Convention on Civil Liability for Oil Pollution Damage $^{85}$ of 1969, as amended by the 1976 and 1992 protocols, are recognized as having the force of Canadian law by the $M L A,{ }^{86}$ which applies to ship-source pollution occurring in Arctic waters.

The $M L A$, however, does not apply to pollution emanating from "a drilling ship that is on location and engaged in the exploration or exploitation of the seabed or its subsoil in so far as an escape or discharge of [a pollutant] emanates from those activities." ${ }^{87}$ Nor do the pollution provisions located in Part 7 of the Act apply "to a floating storage unit or floating

$80 \quad$ Supra note 8.

$81 \quad$ McDorman, supra note 78 at 233.

82 European Commission, "Maritime Policy actions: Multilateral governance," online: European Commission <http://www.ec.europa.eu/maritimeaffairs/arctic_governance_en.html>.

83 European Commission, "Maritime Policy actions: Transport," online: European Commission <http:// ec.europa.eu/maritimeaffairs/arctic_transport_en.html>.

84 An excellent review of the Canadian situation concerning Arctic sovereignty is provided by Ron Macnab in "“Use it or Lose it' in Arctic Canada: Action Agenda or Election Hype?” (2009) 34 Vt. L. Rev. 3. See also Ron Macnab, “A Tale of Two Cities: Washington, Ottawa, and Arctic Governance” Meridian (Fall/Winter 2009) 22, online: Canadian Polar Commission <http://www.polarcom.gc.ca/media.php? mid=3569>

8529 November 1969, 973 U.N.T.S. 3, U.K.T.S. 1975 No. 106 (partially terminated).

$86 \quad$ Supra note 30, Part 6.

Ibid., s. 101(2). 
production, storage and offloading unit unless it is carrying oil as a cargo on a voyage to or from a port or terminal outside an offshore oil field." 88

Pollution caused by the transportation of oil, as opposed to its production, are addressed in the MLA, whereas oil and gas exploration and production are addressed in the Canada Oil and Gas Operations Act. ${ }^{89}$ There is an exception to this, as we shall see when we come to consider the $A W P P A^{90}$ and the Arctic Waters Pollution Prevention Regulations. ${ }^{91}$

\section{B. The CANADA SHIPPING ACT, 2001}

The CSA is the major piece of Canadian legislation generally applicable to shippingrelated issues. The pollution prevention provisions of the Act are related to prosecutions but generally exempt the oil and gas industry and do not apply

in respect of a discharge of oil or gas from a vessel that is on location and engaged in the exploration or drilling for, or the production, conservation or processing of, oil or gas in an area described in paragraph 3(a) or (b) of the Canada Oil and Gas Operations Act, in so far as the discharge emanates from those activities. ${ }^{93}$

There are a number of regulations made under the CSA that are relevant to Arctic waters, including the Ballast Water Control and Management Regulations. ${ }^{94}$ These regulations are applicable to the shipping safety control zones in the Arctic, and waters in the exclusive economic zone of Canada. ${ }^{95}$ The issue of discharges of waste is one of concern to the offshore industry and is more particularly dealt with in COGOA.

Transport Canada has the overall responsibility for matters relating to shipping. Within its mandate are such agencies as the Pollution Prevention Branch, the Canadian Coast Guard, and many others. Discharging its responsibilities related to the Arctic, Transport Canada has published a number of guidelines related to Arctic operations, which include TP 11663E, ${ }^{96}$ concerning the operation of tankers and barges in the Arctic, TP 12259E, ${ }^{97}$ which characterizes the relative risk that different ice conditions pose to the structure of different ships, and TP $12260,{ }^{98}$ which describes equivalent structural requirements for Arctic class ships as prescribed by the Arctic Shipping Pollution Prevention Regulations. ${ }^{99}$

Ibid., s. 101(3).

R.S.C. 1985, c. O-7 [COGOA].

Supra note 31.

C.R.C., c. 354.

Supra note 29.

Ibid., s. 186(2).

S.O.R./2006-129.

Ibid., s. 1.

Transport Canada, Guidelines for the Operation of Tankers and Barges in Canadian Arctic Waters, Guideline TP 11663E (Ottawa: Supply and Services Canada, 1997), online: Transport Canada $<$ http://www.tc. gc.ca/publications/en/tp11663e.pdf $>$.

Transport Canada, Arctic Ice Regime Shipping System (AIRSS) Standards, Guideline TP 12259E (Ottawa: Supply and Services Canada, 1998), online: Transport Canada <http://www.tc.gc.ca/ publications/en/tp12259/pdf/hr/tp12259/pdf/hr/tp11663e.pdf>.

Transport Canada, Equivalent Standards for the Construction of Arctic Class Ships, Guideline TP 12260 (Ottawa: Supply and Services Canada, 1995), online: Transport Canada <http://www.tc.gc.ca/ publications/bill/tp12260/pdf/hr/tp12260e.pdf>.

C.R.C., c. 353. 
The Arctic Canada Traffic System, known as NORDREG, is operated by the Marine Communications and Traffic Services personnel. It keeps track of all traffic north of $60^{\circ}$ latitude. In August 2008 the reporting zone was extended to 200 miles, thus making it consistent with the AWPPA's 200 mile jurisdiction and with Canada's claims to Arctic sovereignty. Reporting to NORDREG has recently been made compulsory.

\section{THE OCEANS ACT}

As noted above, this statute has brought the UNCLOS regime of maritime rights for coastal states into Canadian legislation.

Section 20 confirms that Canadian federal laws apply on continental shelf installations engaged in hydrocarbon exploration. Part II of the Act sets in motion the development of an “oceans management strategy" 100 for Canada and its waters. Section 35 defines a "marine protected area" as "an area of the sea that forms part of the internal waters of Canada, the territorial sea of Canada or the exclusive economic zone of Canada and has been designated under this section for special protection." ${ }^{101}$ An area off Nova Scotia known as the Gully has been designated as such a marine protected area (MPA). This area is close to two exploration licences.

Canada-Nova Scotia Offshore Petroleum Board (CNSOPB) policy prohibits oil and gas activity within the Gully MPA boundaries. A number of years ago the CNSOPB published a document concerning environmental assessments and potential exploratory drilling activities on these exploration licences. ${ }^{102}$ In 2009, the EnCana Corporation (EnCana) published a document concerning the installation of well-head protection structures in, inter alia, the Sable Island area and the Gully MPA. ${ }^{103}$ This document annexes the "EnCana Code of Practice for the Gully MPA.”104 The Code provides in part that

EnCana will not conduct activities inside the Gully MPA. In addition, no vessels are permitted within the Gully MPA and aircraft in regular transit to and from any vessels, drilling units, or facilities are restricted to flying at a height of at least $500 \mathrm{~m} .{ }^{105}$

Supra note 12, ss. 28-39.12. Section 29 describes the strategy:

The Minister, in collaboration with other ministers, boards and agencies of the Government of Canada, with provincial and territorial governments and with affected aboriginal organizations, coastal communities and other persons and bodies, including those bodies established under land claims agreements, shall lead and facilitate the development and implementation of a national strategy for the management of estuarine, coastal and marine ecosystems in waters that form part of Canada or which in Canada has sovereign rights under international law. Ibid.

102 CNSOPB, Exploratory Drilling Activities on Exploration Licences 2415 and 2416: Scoping Document for the Environment Assessment (Halifax: CNSOPB, 2006), online: CNSOPB <http://www.cnsopb.ns. ca/pdfs/30008.22_Scoping_Document_Drilling.pdf $>$.

103 EnCana, 2009 Wellhead Protection Structures Installation Environmental Protection Plan/ Environmental Effects Monitoring Plan (29 April 2009), online: CNSOPB <www.cnsopb.ns.ca/ pdfs/30008.23_2009_Wellhead_Protection_Structures_Installation_EPP-EEMP.pdf>. 
This Code also highlights concerns with marine mammals, the effects of noise on the area, and the potential effects of spills. ${ }^{106}$

These restrictions on activities in areas designated as MPAs have their birth in the OSPAR Commission. ${ }^{107}$

In connection with the Gully, regulations have been made pursuant to the Oceans Act. ${ }^{108}$ These regulations provide for varying degrees of management of the MPA and include designated "prohibited activities.” One such prohibited activity is to

carry out any activity - including depositing, discharging or dumping any substance, or causing any substance to be deposited, discharged or dumped - in the Gully Marine Protected Area or in the vicinity of that Area that is likely to result in the disturbance, damage, destruction or removal of anything referred to in paragraph $(a)$ or $(b){ }^{109}$

Things not to be removed include any living marine organism or any part of its habitat. ${ }^{110}$

As part of its mandate under Part II of the Ocean Act, concerning oceans management strategy, the government has also identified the Beaufort Sea as a large ocean management area (LOMA). As noted on the Fisheries and Oceans Canada website, LOMAs "are delineated so that ecosystem health and economic development issues within their boundaries can be addressed and suitably managed.”111

The United Nations Environment Programme (UNEP) has a very active program in connection with the designation of MPAs. In describing protected areas their website says:

Protected areas are very important for conserving biodiversity. In these areas, human activities are managed to achieve specific conservation goals, for example, to protect a certain species or to conserve a representative habitat or ecosystem. The Arctic has many terrestrial protected areas, but is generally lacking in marine protected areas (MPAs). As the climate warms and the sea ice melts, there will be greater access for activities such as fishing, oil and gas exploration, and tourism. MPAs will become increasingly important to protect Arctic marine ecosystems. ${ }^{112}$

Given the experience to date in eastern Canada, the development of MPAs in the Arctic is an area to watch.

Ibid.

OSPAR Guidance, supra note 44 at 8.

Gully Marine Protected Area Regulations, S.O.R./2004-112.

Ibid., s. 4(c) [emphasis added].

Ibid., s. 4(a).

Government of Canada, "Purpose and Goals," online: Fisheries and Oceans Canada <http://www.dfompo.gc.ca/oceans/marineareas-zonesmarines/loma-zego/purpose-but-eng.htm>.

UNEP \& Grid-Arendal, "Protected Areas, Arctic and Antarctic,” online: UNEP/Grid-Arendal < http:// maps.grida.no/go/graphic/protected-areas-arctic-and-antarctic>. 


\section{The Arctic Waters Pollution Prevention ACt ${ }^{113}$}

The original iteration of this statute applied to 100 miles offshore. As part of Canada's continuing assertion of sovereignty in the Arctic, in 2009 it was amended to extend its application to 200 miles. ${ }^{114}$

The AWPPA generally prohibits the "deposit of waste of any type in the arctic waters."115 The statute imposes civil liability resulting from prohibited deposits on a number of entities including "any person who is engaged in exploring for, developing or exploiting any natural resource on any land adjacent to the arctic waters or in any submarine area subjacent to the arctic waters."116 "Waste" is defined very generously and certainly would include the products of oil exploration and development. ${ }^{117}$

The Arctic Waters Pollution Prevention Regulations set the limits of liability for the offences created by the AWPPA. The limit for "an operation engaged in exploring for, developing or exploiting oil and gas” is $\$ 40$ million. ${ }^{118}$ The nature of the liability is described in the AWPPA as "absolute and does not depend on proof of fault or negligence." ${ }^{119}$ Arguably this limit is not relevant where fault or negligence is involved.

The Arctic Shipping Pollution Prevention Regulations are the most important set of regulations governing shipping in the Arctic. The regulations prescribe "shipping safety control zones" ${ }^{20}$ in the Arctic and define the types of vessels that are permitted to navigate in these zones, the times of year when such navigation can take place, and many other requirements such as having on board Arctic pollution prevention certificates ${ }^{121}$ and ice navigators. ${ }^{122}$ These regulations extend to vessels that are not Canadian flagged and, in the context of the transportation of oil, s. 6 of the regulations is directed to the movement of oil tankers and sets out seasonal travel restrictions in Arctic waters based on the type and construction of the tanker, and the quantity and characteristic of the ice on the intended route. $^{123}$

\section{E. The CoAsting Trade ACT ${ }^{124}$}

This statute governs the use of foreign ships in the coasting trade of Canada and encompasses waters above the continental shelf of Canada insofar as that relates to "the exploration, exploitation or transportation of the mineral or non-living natural resources of the continental shelf of Canada." 125 This provision recognizes that vessels engaged in

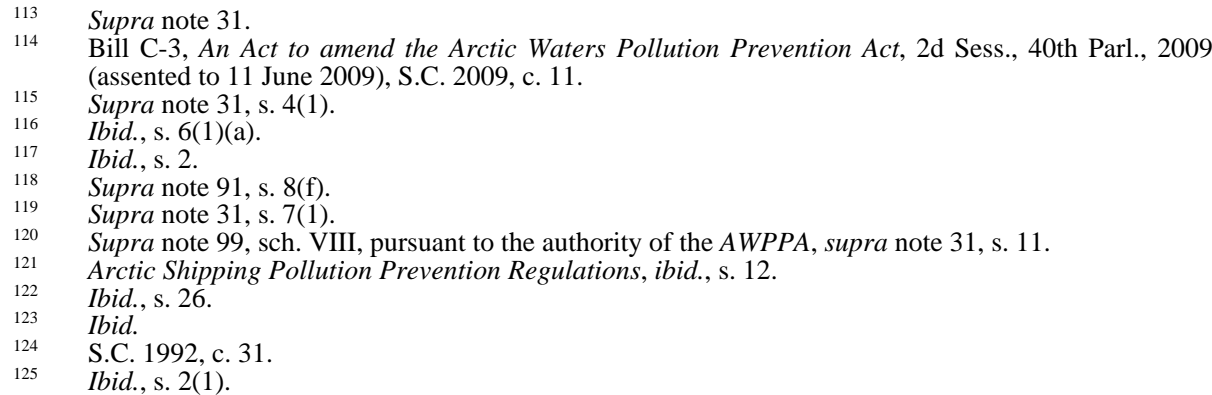


hydrocarbon exploration above the continental shelf are not engaged in international voyages, but are rather present in Canadian water to exploit resources.

Foreign vessels wishing to operate in the oil exploration business are required to apply to the Canadian Transportation Agency (CTA), which, in appropriate circumstances, may issue a Coasting Trade Licence for that vessel's Canadian operation. The question asked by the CTA is whether or not there is a Canadian vessel able to carry out the work for which the foreign vessel is applying. ${ }^{126}$ In addition to the obvious, a "ship" will include most drilling structures commonly associated with offshore oil exploration. ${ }^{127}$

\section{Oil AND Gas LaW ReleVAnt to the ARCTIC}

Petroleum resource management jurisdiction in the Arctic is governed by the $C P R A^{128}$ and COGOA. ${ }^{129}$

The CPRA governs the allocation of Crown lands to the private sector, tenure to the allocated rights, and the setting and collection of royalties. It is the statute under which the federal government provides permission for oil and gas exploration to occur on Crown lands.

COGOA governs the exploration, drilling, production, conservation, processing, and transportation of oil and gas.

These statutes are well-known to Canadian oil and gas lawyers and in this Part we will highlight only those areas that seem to be of direct interest to offshore hydrocarbon exploration.

COGOA applies to waters above the continental shelf. ${ }^{130}$ Petroleum discharges, emissions, or escapes are regulated in cases where such events do not constitute vessel discharges covered by the CSA or the $M L A .{ }^{131}$ Oil and gas discharges, emissions, or escapes are also covered by COGOA. The Act imposes strict liability for actual loss or damage incurred. ${ }^{132}$ Such damages include "loss of income, including future income, and, with respect to any aboriginal peoples of Canada, includes loss of hunting, fishing and gathering opportunities." "133

Effective 2010, a new version of the Canada Oil and Gas Drilling and Production Regulations $^{134}$ came into effect. Coincident with their coming into effect, the NEB issued

Ibid., s. 4.

The Coasting Trade Act definition of "ship" is the same as "vessel” in s. 2 of the CSA, supra note 29, which provides that a vessel "means a boat, ship or craft designed, used or capable of being used solely or partly for navigation in, on, through or immediately above water, without regard to method or lack of propulsion.” Such units as semi-submersible drilling rigs, jack-up rigs, and some Arctic drilling caissons qualify. The Molikpaq, an Arctic drilling caisson that drilled in the Beaufort in the 1980s, was registered as a ship with the Registry of Shipping for Canada.

Supra note 77.

Supra note 89.

Ibid., s. 3(b).

Ibid., s. 24(1).

Ibid., s. 26(2).

Ibid., s. 24(3).

S.O.R./2009-315. 
“draft safety plan guidelines”"135 that are intended to be read with the safety plan requirements of the regulations and to "provide assistance to interested parties in understanding the requirements of the DP Regs and how those requirements could be met." "136 Various aspects of offshore exploration are addressed including:

- When using a MODU, the operator should submit a safety case developed in accordance with the International Association of Drilling Contractors (IADC) Health, Safety and Environment Case Guideline for Mobile Offshore Drilling Units. $^{137}$

- Where marine vessels are used, the operator should take advantage of the ship's International Safety Management (ISM) certification and ensure that the vessel has a valid ISM certificate. ${ }^{138}$

- An operator may rely on a Certificate of Fitness as third party verification of regulatory requirements. The guidelines, however, note that these certificates do not relieve the operator of overall accountability for the equipment. ${ }^{139}$

The NEB has been sensitive to the effect of sound, particularly seismic noises. In 2008, the NEB issued a statement with respect to the mitigation of seismic sound in the marine environment. $^{140}$

One can anticipate that the issue of noise and the environment may well raise its head in connection with the Arctic. It certainly has been an issue with environmental groups in the U.S. Very recently, in Winter v. Natural Resources Defense Council, ${ }^{141}$ the U.S. Supreme Court considered whether sonar use by the U.S. Navy was causing irreparable harm to a number of species of marine mammals, including dolphins, whales, and sea lions. The Court found in favour of the Navy. As with many issues, it is often useful to turn one's attention to what is going on in the U.S. courts.

Recently the NEB decided to review its policy concerning Same Season Relief Well (SSRW) capability in the Beaufort Sea, calling it a matter of "significant public concern."142

Letter from Anne-Marie Erickson, Secretary, NEB to Interested Parties, "Drilling and Production Regulations Consultation Draft Safety Plan Guidelines” (31 December 2009) [“Safety Plan Guidelines”]. All NEB documents can be found online: NEB <http://www.neb-one.gc.ca/>.

$136 \quad$ Ibid. at 1.

137 Ibid. at 10, citing IADC, Health, Safety and Environmental Case Guidelines for Mobile Offshore Drilling Units (1 May 2009) 3.2.1, online: IADC <http://www.iadc.org/hsecase/MODU\%20Offshore \%20Revision\%20Final.pdf>.

"Safety Plan Guidelines,” ibid. The International Safety Management (ISM) Code 2002 is a document produced by the IMO to provide an international standard for the safe management and operation of ships, and for pollution prevention. The Code can be accessed online: IMO <http://www.imo.org/human element/mainframe.asp?topic_id=287>.

139 "Safety Plan Guidelines," ibid. at 18. See also Canada Oil and Gas Certificate of Fitness Regulations, S.O.R./96-114. The comment in the guidelines concerning the continuing obligations of the operator are comparable in the shipping world to the well-known rule that a shipowner cannot delegate to a third party the obligation to have a seaworthy vessel. Letter from Anne-Marie Erickson, Secretary, NEB to Interested Parties, "Statement of Canadian Practice with Respect to the Mitigation of Seismic Sound in the Marine Environment” (14 May 2008). 129 S. Ct. 365 (2008).

Letter from Anne-Marie Erickson, Secretary, NEB to Various Parties, “Canada Oil and Gas Operations Act Withdrawal of Delegation of Power given to the Chief Conservation Officer Regarding all Matters Dealing with Same Season Relief Well Capacity” (24 August 2009) at 1 [“COGOA Withdrawal”]. 
On 5 February 2010, the Board issued a hearing order regarding NEB policy in relation to SSRW capability for drilling in the Beaufort Sea. ${ }^{43}$ The Board solicited written representations from interested parties and arranged for a technical conference. Interestingly, the Board had earlier decided on 13 August 2009, insofar as the SSRW policy was concerned, to withdraw its delegation of powers to its chief conservation officer and indicated that any future matter dealing with SSRW capability would "be directly handled by the Board.”144

The SSRW “policy” has a long history. It was formulated and approved by the Canadian government in the 1970s. The policy was designed to ensure that when a well was being drilled in the Beaufort Sea during the open water season, there would be appropriate drilling equipment in the area that, in the event of a blow-out, could be moved to the site in order to complete a relief well before the ice conditions became so severe that the drilling equipment could no longer operate. This meant that the second unit had to be designated and arrangements put in place to ensure that the unit could move to the location and be used to complete a relief well within a limited period of time, ${ }^{145}$ certainly within the same drilling season. In 1989, when the Canadian Oil and Gas Lands Administration (COGLA) was the Canadian government entity responsible for regulating the offshore, it reviewed the SSRW policy but no changes were made to it. ${ }^{146}$

In 1991, the Canadian government created the Beaufort Sea Steering Committee (BSSC) to assess various concerns relating to government preparedness for an oil spill resulting from an oil well blow-out in the Beaufort Sea. This committee produced a multi-volume report in April 1991. Volume 7 of that report dealt exclusively with the issue of the SSRW. ${ }^{147}$ Volume 7 makes it clear that the SSRW policy was based on the ability of drill ships and their support fleets in the mid-1970s. No change to the SSRW policy was forthcoming from this 1991 review.

As a result of the 2010 NEB decision to review its policy concerning SSRW, a number of oil companies and drilling contractors made written submissions to the NEB. ${ }^{148}$ These submissions are technical in nature and identify a number of issues including:

- $\quad$ The existing SSRW is not feasible as the industry begins drilling in the deepwater Beaufort Sea where there are much “deeper water depths, more severe ice conditions and ... deeper and more complex wells.”149

Letter from Anne-Marie Erickson, Secretary, NEB to Various Parties, "Hearing Order MH-1-2010 regarding National Energy Board Policy for Same Season Relief Well Capability for Drilling in the Beaufort Sea" (5 February 2010). "COGOA Withdrawal," supra note 142 at 1. COGLA Engineering Branch, Policy On Relief Well Drilling "Beaufort Sea”: A Commentary (N.p. COGLA, 1989). Ibid.

BSSC, Report of Task Group Six: Operating Seasons, vol. 7 (Vancouver: BSSC, 1991), online: Arctic Institute of North America <http://pubs.aina.ucalgary.ca/misc/33796.pdf $>$.

These can be accessed online: NEB <www.neb-one.gc.ca/ $>$.

See e.g. Chevron Canada Limited, Submission To National Energy Board Policy Hearing For Same Season Relief Well Capability For Drilling In The Beaufort Sea (22 March 2010) at 6. 
- $\quad$ Ice coverage and the presence of multi-year ice increase as drilling moves towards the edge of the continental shelf. ${ }^{150}$

- Multi-season wells will continue as drilling moves onto the slope of the continental shelf itself. ${ }^{151}$

- $\quad$ Significant technical improvements have been made by the industry since the current SSRW policy was put in place that "allow for a preventative rather than reactive approach" to the relief well issue. ${ }^{152}$

- $\quad$ Completing the drilling of a relief well, the killing of the original well, and the safe suspension of both during a single season is not possible in the deepwater Beaufort Sea. ${ }^{153}$

These articulated issues highlight a number of points. First, they recognize that drilling in the Beaufort is increasingly moving to deeper water, and potentially out to the continental shelf itself. This will highlight issues for oil companies related to UNCLOS art. 82, discussed above. ${ }^{154}$ The number of submissions is also indicative of a renewed interest in deepwater drilling in the Beaufort Sea and the Arctic.

The SSRW review was initiated before the April 2010 explosion and sinking of the transocean rig Deepwater Horizon in the Gulf of Mexico. That event caused the NEB to cancel its proposed technical hearings concerning SSRW capability. It is, however, still useful to consider submissions that had been made, since they certainly highlight the then current views of the oil companies and contractors.

In response to the Deepwater Horizon incident, the NEB, in June 2010, announced a "Public Review of Arctic Safety and Environment Offshore Drilling Requirements." ${ }^{155}$ This review is intended to "engage industry and the public in examining the best available information concerning the hazards, risks and mitigation measures associated with offshore drilling activities in the Canadian Arctic and the measures to both prevent and respond to accidents and malfunctions.”156

$150 \quad$ Ibid. at 31

$151 \quad$ Ibid. at 36.

152 See e.g. Letter from Gary Sykes, VP Canadian Arctic BU, ConocoPhillips to Anne-Marie Erickson, Secretary, NEB, "ConocoPhillips' Submission in accordance with NEB Hearing Order MH-1-2010 Same Season Relief Well Capacity for Drilling the Beaufort Sea” (19 March 2010) at 2.

153 See e.g. British Petroleum, National Energy Board Hearing Order MH-1-2010 Review of Policy on Same Season Relief Well Capability for Drilling in the Beaufort Sea: Written Submission of BP Exploration Operating Company Limited (22 March 2010) at para. 21.

154 Supra note 4. Competing interests in hydrocarbons may straddle the OCS of a coastal state and its 200 mile economic zone. Since a royalty payment due under art. 82 is dependent on production, one can envisage disputes concerning the common law rule of capture: see ISA Study No. 4, supra note 17 at 62. and Environmental Offshore Drilling Requirements” (10 June 2010). Ibid. at 3. 


\section{The Aboriginal Issues}

The federal government has concluded a number of land claim agreements in the North. The major ones for consideration in this Part are the agreements with the Nunavummiut and Inuvialuit people of northern Canada. These agreements play an important part in the consideration of future oil and gas developments offshore northern Canada. The major agreements are the Inuvialuit Final Agreement, ${ }^{157}$ the Nunavut Land Claims Agreement, ${ }^{158}$ and, to some extent, the North Baffin Regional Land Use Plan ${ }^{159}$ (collectively, the Agreements). The Agreements must be considered with the pronouncements of the Supreme Court in Haida Nation v. British Columbia (Minister of Forests), ${ }^{160}$ a 2004 decision rendered subsequent to the Agreements. This decision both establishes and defines the duty of the Crown to consult with, and accommodate, the Indigenous peoples of the Arctic, particularly where government activities have the potential of negatively impacting Aboriginal or treaty rights.

In this Part we discuss the Agreements and the duty to consult, followed by a consideration of two cases currently before the Supreme Court of Canada that have the potential to impose a continuing duty to consult on already concluded final agreements and, second, to enlarge beyond government the actual obligation to consult. Finally we discuss the interaction of offshore oil and gas development with Aboriginal issues and point out some international developments in matters involving Aboriginal title to sea spaces.

\section{A. The InUVialuit Final AgreEment}

The IFA is the first land claim settled north of the 60th parallel in Canada. The IFA gives the Inuvialuit the right to fully participate in decision-making processes that may affect conservation and economic development related to the Beaufort Sea. ${ }^{161}$

The Inuvialuit have legal control over their land, with ownership of 91,000 square kilometres (35,000 square miles) of land including 13,000 square kilometres (5,000 square miles) with subsurface rights to oil, gas, and minerals. The IFA is based on sustainable development and one of the primary goals of the IFA is "to enable Inuvialuit to be equal and meaningful participants in the northern and national economy and society” while preserving their "cultural identity and values within [the] changing northern" environment. ${ }^{162}$ Along with the goal of protecting and preserving "Arctic wildlife, environment and biological

Indian and Northern Affairs Canada, The Western Arctic Claim: The Inuvialuit Final Agreement (Ottawa: Indian and Northern Affairs Canada, 1984), online: Collections Canada <http://www. collectionscanada.gc.ca/webarchives/20051229020142/http://www.ainc-inac.gc.ca/pr/agr/ inu/wesar_e.pdf> [IFA]. For settlement legislation see the Western Arctic (Inuvialuit) Claims Settlement Act, S.C. 1984 , c. 24.

Agreement Between the Inuit of the Nunavut Settlement Area and Her Majesty the Queen in Right of Canada, 25 May 1993, online: Nunavut Court of Justice <http://www.nucj.ca/library/bar_ads_mat/ Nunavut_Land_Claims_Agreement.pdf> [NLCA]. For settlement legislation see the Nunavut Land Claims Agreement Act, S.C. 1993, c. 29.

Nunavut Planning Commission, North Baffin Regional Land Use Plan (Cambridge Bay, Nunavut: Nunavut Planning Commission, 2000), online: Nunavut Planning Commission <http://www.nunavut.ca/ files/North\%20Baffin\%20Regional\%20Land\%20Use\%20Plan.pdf> [NBRLUP]. 2004 SCC 73, [2004] 3 S.C.R. 511 [Haida]. 
productivity,” these goals will have a significant impact on offshore developments in the Arctic region. ${ }^{163}$

The language of the IFA is the first source of legal authority when dealing with issues of consultation, accommodation, or future rights and title claims by the Inuvialuit over the Arctic sea beds. However, the common law and the Constitution always play a role in determining rights of Aboriginal peoples. The definition of "development" in the IFA is important when considering offshore development in the Arctic. The definition includes "any commercial or industrial undertaking or venture, including support and transportation facilities related to the extraction of non-renewable resources from the Beaufort Sea, other than commercial wildlife harvesting." 164 The IFA provides explicit water rights and the requirement of participation agreements with the Inuvialuit people, both of which may have a significant impact on offshore development in the Arctic as the Inuvialuit people have been "granted title In fee simple absolute to the beds of all lakes, rivers, and other water bodies found in Inuvialuit lands." 165 The Crown does retain ownership of all waters in the Inuvialuit Settlement Region. However, as a consequence of the common law duty to consult and the rights granted in the IFA, the Inuvialuit people play an important role in the economic development of the Arctic region.

The Arctic Offshore Oil and Gas Guidelines provide a useful summary of the government agencies at play. The NEB, pursuant to COGOA, has the primary responsibility for authorizing oil and gas activity in Canada's Arctic region, while Indian and Northern Affairs Canada is responsible for issuing licences for exploration, significant discovery, and development licences under the CPRA. ${ }^{166}$

The development activity taking place in the Beaufort Sea will certainly attract the provisions of the IFA, particularly s. 11, which outlines the environmental screening and review process, and s. $7{ }^{167}$

\section{B. The Nunavut Land Claims AgreEment}

The NLCA is the largest Aboriginal land claim settlement in Canadian history. When the NLCA was signed, contemporaneous legislation created the new territory of Nunavut on 1 April 1999. The NLCA gives title to Inuit-owned lands measuring about 350,000 square kilometres (of the total area of Nunavut of 1.9 million square kilometres), of which about 35,000 square kilometres include mineral rights. The first objective of the NLCA to have a direct impact on offshore development in the Arctic is

See Jessie Sloan, Gordon Erlandson \& Louise Beinhauer, Oil \& Gas Approvals in the Beaufort Sea: a guide to regulatory approval processes for oil and natural gas exploration and production on Canada's Frontier Lands in the Beaufort Sea (Victoria: Erlandson \& Associates, 2002), online: Oil and Gas Guides <http://www. oilandgasguides.com/guides/nwt-bft/nwt-bft.pdf>. 
to provide for certainty and clarity of rights to ownership and use of lands and resources, and of rights for Inuit to participate in decision-making concerning the use, management and conservation of land, water and resources, including the offshore. ${ }^{168}$

Article 11 of the NLCA addresses land use planning. "Land" is defined to include, "water and resources including wildlife.”169 The Nunavut Planning Commission (NPC) has an important mandate under the NLCA to prepare and implement land use plans that guide and direct resource use and development. Land use plans tell others how Inuit want the land and water used today and into the future. Any development in the Arctic that impacts the area covered by the NLCA is bound by a consultation and approval process as outlined in art. 12 of the $N L C A$, Development Impact. The process to be undertaken under art. 12 is carried out by the Nunavut Impact Review Board. Because of settlement of land claim agreements, the approval of projects or issuing of licences under the CPRA requires different environmental assessment processes in different regions of the Arctic. ${ }^{170}$ Article 12 of the NLCA outlines the sole environmental assessment process applicable to the Nunavut Settlement Region, which can be a lengthy process.

\section{The North Baffin REgional LAND USE PlaN}

The NBRLUP was effective 20 June 2000. It was prepared by the NPC in accordance with the procedure for public consultation and government review and required by art. 11 of the $N L C A$. Since the original $N B R L U P$ was approved, the $N L C A$ has come into effect. As noted above, the NPC was established as a result of the creation of the NLCA. The NPC established a process of land use planning throughout Nunavut. The land users want a balance between uses in the region. The NPC, after a review and consultation with the people in the affected communities and other interested parties, believed that "general direction on how land should be used and how land users should cooperate in their use of the land continues to be the best way to establish a balance between users.”171

The original NBRLUP has been revised since the inception of the NLCA. The revised land use plan encourages and supports current initiatives for community involvement in land use decision-making, and introduces new means of accomplishing this involvement. Article 3.5 addresses Marine and Terrestrial Transportation in the following terms: "The NPC does not support year-round Arctic shipping because of the uncertainty about its effects on regional residents and the environment and wildlife." ${ }^{172}$

Articles 3.5.1 to 3.5.12 provide a detailed analysis of the requirements for shipping activity under the terms of the NBRLUP. ${ }^{173}$

Similar issues concerning mineral exploration and production are outlined in art. 3.6. The NPC recognizes "the value and contribution of mineral exploration and development" in the

Supra note 158 at 1.

Ibid., art. 11.1.2.

Sloan, Erlandson \& Beinhauer, supra note 166.

Supra note 159 at 3.

Ibid.

Ibid. 
northern region, and supports industry's access to land for exploration while at the same time emphasizing the need of industry to be "sensitive to the changed approval process introduced under the NLCA." ${ }^{174}$

Article 3.7 of the NBRLUP addresses similar concerns with respect to oil and gas exploration and production and provides for the duty to consult with the Aboriginal peoples of the Arctic region that are affected by this type of development. Indian and Northern Affairs Canada, as well as relevant departments of the Nunavut government have a responsibility to ensure the communities receive "the best information available concerning the risks and benefits of oil and gas exploration and production" and promote information sharing among the local people and those that have knowledge or "experience in drilling, in ice-infested waters and in strong ocean currents (e.g., residents, researchers, drilling operators in the Beaufort Sea and the east coast regions)." "175 The government must ensure that communities are involved in setting research priorities and participating in research while being able to access independent (including government and industry) sources of information. It must be clear that the communities comprehend the research results. ${ }^{176}$ Last, oil and gas exploration companies must continually work to reduce any negative effects that their work may have on the environment. Their activities must align with the rights and benefits afforded the Aboriginal peoples through the Impact and Benefits Agreements in the NLCA. ${ }^{177}$

\section{The Duty To Consult Aboriginal Peoples}

Consultation is any discussion, negotiation, or meeting used to justify Crown infringement of Aboriginal and treaty rights. The duty to consult is constitutionally-based law that provides a form of protection to Aboriginal rights and treaty rights from activities that can have a negative impact on those rights. The protection includes both procedural and substantive rights. Factors that are integral to a successful consultation process with Aboriginal peoples include early notification in the development process, well in advance of the required permits, licences, leases, and other approvals. ${ }^{178}$ It is important to bear in mind, however, that although consultation is the first step, accommodation is also a key step in the process. Early engagement of the Indigenous peoples in the Arctic is integral to a successful project.

The duty of the government to consult with, and potentially accommodate the needs and interests of, Aboriginal peoples is grounded in the principle of the honour of the Crown, which must be given a broad, liberal understanding, best stated by the Supreme Court of Canada in Haida. While the asserted, but unproven, Aboriginal rights and title are insufficiently specific for the honour of the Crown to mandate that the Crown act as a fiduciary, the Crown, acting honourably, cannot casually run roughshod over Aboriginal interests, particularly where claims affecting these interests are being sought in the process

Ibid., art. 3.6.

Ibid., art. 3.7.4.

Ibid.

Ibid., art. 3.7.7.

Stuart C.B. Gilby \& Naiomi Metallic, “Consultation/Accommodation Litigation Developments Across Canada” (Paper presented at the 2d Annual INSIGHT Aboriginal Law and Economic Development Forum, Halifax, 18 February 2010) [unpublished]. 
of treaty negotiation and proof. In Haida, the Court held that "the duty to consult and accommodate is part of a process of fair dealing and reconciliation that begins with the assertion of sovereignty and continues beyond formal claims resolution."179

In Haida the Court held that the Crown has a legal duty to consult with Aboriginal peoples where there is a proven Aboriginal or treaty right, potential Aboriginal or treaty right, or a "credible but unproven claim." " 80 When assessing whether or not there is an existing duty, the question is whether the government had real or constructive knowledge of the potential existence of Aboriginal rights or title, and contemplated conduct that may negatively impact these rights or title. ${ }^{181}$

The Crown does not have a duty to reach an agreement with the Aboriginal peoples but it must commit to participate, in good faith, in a meaningful consultation process. ${ }^{182}$ Consultation implies the possibility of a duty to accommodate Aboriginal interests. Thus far, entities other than the Crown have not been held responsible for the failure to discharge the Crown's duty to consult and accommodate Aboriginal peoples. The duty stems from the honour of the Crown and its assumption of sovereignty over land and its resources that were previously held by the Aboriginal peoples. This duty cannot be delegated to third parties, but this does not mean that third parties can never be held liable to Aboriginal peoples. If third parties act negligently toward Aboriginal peoples where a duty of care exists, or if third parties breach contracts with Aboriginal peoples, they can be held legally liable. ${ }^{183}$

\section{ARCTIC CONSUltation With ABORIGINALS}

As noted above, the Government of Canada has a long history of consultation with the Inuvialuit people of the Arctic. Negotiations began in 1974, and the IFA concluded the process. Many provisions in the IFA describe the consultation requirement that the Government of Canada has with the Inuvialuit people. This requirement includes matters involving Crown land, water rights, administration of rights, participation agreements, environmental screening, and more. These processes have been imbedded in the negotiation process involving development in the Inuvialuit Settlement Region. More specifically, s. 7 of the IFA states that, subject to the IFA, holders of oil and gas, coal, mineral, and quarrying rights on Inuvialuit s. 7(1)(a) lands (4,200 square miles of land in the Western Arctic Region and 800 square miles of land in Cape Bathurst) and holders of quarrying rights issued before 31 December 1983 on Inuvialuit s. 7(1)(b) lands (Inuvialuit lands selected by agreement between the Committee for Original Peoples' Entitlement and Canada, as described in s. 9(5) of the IFA), are entitled to enjoy the rights (including renewals) until they are terminated. ${ }^{184}$ Canada must continue to administer the rights of these interest holders. Certain discretionary decisions must be "made with the consent of the Inuvialuit, where the economic interest of the Inuvialuit is prejudiced" and the "[a]dministration of the rights can be transferred to the 
Inuvialuit, if the holder and the Inuvialuit agree.”185 Section 7(75) of the IFA refers specifically to the extraction of subsurface resources in the Pingo Canadian Landmark. It states that "[a]ny future exploration for or extraction of the subsurface resources of the Pingo Canadian Landmark shall be carried out from outside the site in a manner that does not damage the pingos.”186 The government's duty to consult is clearly outlined in s. 7(73) which holds that " $[t]$ he Pingo Canadian Landmark shall be managed under the National Parks Act, in consultation with the Inuvialuit Land Administration and the people of Tuktoyaktuk, as a joint management regime.” ${ }^{„ 87}$ Finally, every application for exploration, development, or production rights on Crown lands within the Inuvialuit Settlement Region must apply general government guidelines relating to social and economic interests to favour Aboriginals as per s. 16 of the IFA. ${ }^{188}$

Pursuant to the NLCA, the NPC was created as an independent public agency, drawing its authority from the NLCA. The NPC has distinct authority and decision-making power and it is the NPC's responsibility "to make the final decisions on how land use plans will be developed and how the plans will manage the land in Nunavut."189 The NPC has an important mandate under the NLCA to prepare and implement land use plans that guide and direct resource use and development. Land use plans tell others how Inuit want the land and water used today and into the future. Because of settlement of land claim agreements, the approval of projects or issuing of licences under the CPRA requires different environmental assessment processes in different regions of the North. ${ }^{190}$ This is one example of the type of communication and consultation the government must have with the Aboriginal peoples when considering economic development in the Arctic region. This is particularly important because the oil and gas reserves in Nunavut are among some of the largest and have been lying dormant since 1985. As well, the Nunavut government has no control over the development of the offshore oil and gas market, as that is the jurisdiction of the federal government, with all the decision-making power being in southern Canada. ${ }^{191}$

Under the NBRLUP, there are many processes to be followed when considering development in the North Baffin region of the Arctic. Activities involving the development of shipping routes, mining exploration, and oil and gas exploration and production all require a consultation process with the North Baffin people. The NPC recognizes the value and contribution of mineral exploration and development in the northern region and supports industry's access to land for exploration, while at the same time it emphasizes industry's need to be sensitive to the changed approval process introduced under the NLCA. There is a need for adequate communication and consultation prior to commencement of exploration

Indian and Northern Affairs Canada, Northwest Territories Inuvialuit Settlement Region Lands (Ottawa: Minister of Indian Affairs and Northern Development, 1998) at para. 2.3.4.2, online: Indian and Northern Affairs Canada <http://www.ainc-inac.gc.ca/enr/lds/pubs/jrlr/b2nwt-eng.pdf>.

Supra note 157.

Ibid.

Ibid.

Nunavut Planning Commission, “About the Commission,” online: Nunavut Planning Commission $<$ http://www.nunavut.ca/en/about-commission>.

Sloan, Erlandson \& Beinhauer, supra note 166.

Gabriel Zarate, “NPC promises draft Nunavut land use plan by fall” Nunatsiaq Online (24 March 2010), online: Nunatsiaq Online <http://www.nunatsiaqonline.ca/stories/article/98767_npc_promises_draft_ nunavut_land_use_plan_by_fall $>$. 
or other work, and the necessity to take into account the very real desire of the people of the region to share in the benefits that mining, oil, and gas produces. ${ }^{192}$

\section{DEVELOPMENTS IN THE JURISPRUDENCE ON CONSULTATION AND ABORIGINAL RIGHTS}

\section{a. Little Salmon/Carmacks First Nation}

$$
\text { v. Yukon (Minister of Energy, Mines and Resources) }{ }^{193}
$$

In this case, Little Salmon/Carmacks First Nation brought a claim against the Yukon government for failure "to comply with a legal duty to consult and, where possible, accommodate Little Salmon/Carmacks in respect of an application by Larry Paulsen for an agricultural grant of Crown land located in the traditional territory of the First Nation and the trapline of Johnny Sam, a member of Little Salmon/Carmacks.”194 This case was heard by the Supreme Court of Canada in 2009. It has the potential to affect what may have been considered to be the finality of existing comprehensive land claim agreements, including the IFA and the NLCA. Notwithstanding the fact that an agreement may be called a final agreement, the trial judge in Little Salmon ruled that this does not abrogate the common law duty to consult with respect to final agreements. ${ }^{195}$ The Yukon Court of Appeal, while finding that the duty to consult had been met by the Yukon government, reaffirmed the ruling of the Supreme Court in R. v. Kapp, ${ }^{196}$ that "there can be no doubt that the duty to consult is recognized as a constitutional duty."197

The Yukon government had argued "that the duty to consult and accommodate does not apply where the duty to consult has been defined and limited to specific circumstances in the Final Agreement." ${ }^{\prime 98}$ They also argued that the "honour of the Crown" does apply to the final agreement, but it should not be used to "undermine the certainty" intended to be achieved by a final agreement. ${ }^{199}$ The Yukon Court of Appeal disagreed.

The following passage from Little Salmon reiterates the positions of both parties and clarifies the issue:

The Yukon Government acknowledges that the honour of the Crown applies to the terms of the Final Agreement. However, it says that the right to transfer land in the Traditional Territory of the First Nation is not limited by any term in the Final Agreement. It further states that the interpretation of the Certainty clause and the specific terms of the duty to consult set out in the Final Agreement support the proposition that there is no other duty to consult that should be applied. In its own words:

The respondents say that any common law duty to consult and accommodate which might otherwise have arisen in this case has been replaced by the rights set out in the Final Agreement which is a land

\footnotetext{
$192 \quad$ Ibid.

1932008 YKCA 13, 296 D.L.R. (4th) 99 [Little Salmon (C.A.)].

$194 \quad$ Ibid. at para. 2.

1952007 YKSC 28, [2007] 3 C.N.L.R. 42 [Little Salmon (S.C.)]

1962008 SCC 41, [2008] 2 S.C.R. 483.

$197 \quad$ Supra note 193 at para. 88.

198 Little Salmon (S.C.), supra note 195 at para. 5.

Ibid.
} 
claims agreement within the meaning of section 35 of the Constitution Act, 1982 and thus a constitutionally entrenched treaty.

The primary objective of the Final Agreement was to bring about a reconciliation of government interests and aboriginal rights by giving the parties to the treaty certainty as to the nature and extent of their rights and obligations, including the rights of the parties to own and use lands. To add to or alter the nature of those Final Agreement obligations would actually challenge the certainty the parties wished to achieve and thereby undermine the process of reconciliation.

By carrying out its obligations to the First Nation under the treaty, Yukon acts consistently with the honour of the Crown. While the honour of the Crown infuses the interpretation of the treaty, it should not be invoked to undermine the certainty that this modern treaty is intended to achieve. ${ }^{200}$

Finally, the Yukon government submitted that "its consultation with Yukon First Nations with Final Agreements is not a legal obligation but good practice and the same policy applies to municipal governments, non-government organizations and private citizens." ${ }^{201}$ This is one of the issues to hopefully be determined by the Supreme Court shortly.

The outcome of this case may have considerable impact on the sanctity of final agreements when considering future developments in Arctic waters. The agreements that are currently in place - the IFA, the NLCA, and the NBRLUP — all contain provisions for the rights of Indigenous peoples. This was also the case in Little Salmon, which contained a provision in the final agreement that "Settlement Agreements shall not affect the ability of aboriginal people of the Yukon to exercise, or benefit from, any existing or future constitutional rights for aboriginal people that may be applicable to them."202

Little Salmon clearly raises the possibility that the extent of the Crown's singular obligation to consult Indigenous peoples may not end with the language of a final agreement. What this case tells us is that despite the consultation language in final agreements, this may not be the extent of the Crown's obligation to consult Indigenous peoples.

\section{b. Carrier Sekani Tribal Council \\ v. British Columbia (Utilities Commission) ${ }^{203}$}

This appeal is scheduled to be heard by the Supreme Court of Canada in May 2010. The decision in this case is integral to the extent of the duty owed by administrative bodies to consult Aboriginal peoples. 
Rio Tinto Alcan Inc. (Alcan) had developed both an aluminum smelter in Kitimat and power facilities in Kemano, a nearby community, in order to provide power to their facilities. The construction of the power facilities in the 1950s involved the creation of reservoir as well as the rerouting of the Nechako River. The Crown granted Alcan the necessary water licences needed to carry out this construction and operation. British Columbia Hydro and Power Authority (B.C. Hydro) wanted to buy electricity from Alcan in accordance with an energy purchase agreement (EPA) made in 2007.

The Carrier Sekani Tribal Council alleged that the Crown did not fulfill its duty to consult before B.C. Hydro entered into the EPA, and sought to be heard by the British Columbia Utilities Commission (BCUC). The interest of the Carrier Sekani was in water and related resources. They claimed that the diversion of water for Alcan's use was an infringement of the Carrier Sekani's rights and title, as they were never consulted. The British Columbia Court of Appeal reiterated the language of Haida that the duty to consult does not necessarily include a duty to agree or to make compromises; rather, the duty to consult must be open to accommodation when necessary. The Court found that "B.C. Hydro, as a Crown corporation, was taking commercial advantage of an assumed infringement on a massive scale, without consultation.”204 The Court of Appeal found in favour of the Carrier Sekani and ruled that the matter be sent back to the BCUC to hear arguments on whether there was a duty to consult and if necessary, accommodate, and if so, was that duty met by the Crown in respect of the filing of the EPA. This case is important since it may have the effect of extending the duty to consult beyond Crown corporations to any administrative body that is in the position of authorizing and issuing permits that allow activities to occur that may have a negative impact on Aboriginal rights or title.

The NEB is very cognizant of the extent and nature of the duty to consult. In July 2008, the NEB published a commentary entitled "Consideration of Aboriginal Concerns in National Energy Board Decisions.”205 This document attempts to explain how the Board takes into account the rights or interests of Aboriginal peoples in reaching its decisions. It outlines the ways in which it requires project applicants to consider Aboriginal concerns. Apparently aware of issues concerning the duty to consult, the NEB states:

\footnotetext{
Because the Board is a quasi-judicial tribunal and operates much like a court, it can only consider evidence that is filed by the applicant and any interested parties in the hearing. The common law rules of natural justice mean that the Board cannot engage in one-on-one discussions with any interested parties outside of the hearing process. However, the Board does take steps to ensure that it has sufficient evidence before it makes its decision, including evidence on the impact the proposed project may have on Aboriginal peoples. $^{206}$
}

\section{E. ARCTIC OIL AND Gas ANd Aboriginal InTERESTS}

According to the Beaufort Sea Regional Strategic Plan of Action, "[t]here is a renewed interest in oil and gas exploration and development in the Mackenzie Delta-Beaufort Sea

205 NEB, "Consideration of Aboriginal Concerns in National Energy Board Decisions” (July 2008). Ibid. at 1 . 
region of Canada's western Arctic.”207 The offshore oil and gas situation in the Arctic region is much different today than it was two decades ago when oil and gas play in the offshore was at its all time high. The IFA is the most relevant land claim agreement, which is also influenced by land claims in the Yukon. This land claim settlement process has served to affirm modern day forms of governance and the role of the region's Indigenous and local inhabitants in the planning process, such as offshore co-management regimes and environmental assessment processes, details of which can be found at Appendix III of the IFA. Under the 1993 Canada-Yukon Oil and Gas Accord, ${ }^{208}$ the federal government made a commitment to negotiate a shared offshore management regime and revenue sharing arrangement in the Beaufort Sea with the Yukon government and it is expected that the same responsibility for the management of oil and gas in the Northwest Territories will be similar under the devolution process.

Oil and gas activities will have a significant impact on the region, particularly for the Inuvialuit, as well as the Northwest Territories and Yukon. Though this opportunity will offer benefits and opportunities, such as employment and business opportunities and increased government revenues, it also has the potential for adverse impacts, both social and environmental. Since the oil and gas activity began in the Beaufort, much knowledge has been gained, from reports such as Environmental Impacts of Arctic Oil and Gas Development $(1975)^{209}$ and the Beaufort Sea Project Technical Report Series (1977), to more recent initiatives like the Northern Oil and Gas Action Program (NOGAP) and the Environmental Studies Research Funds (ESRF), ${ }^{210}$ but challenges remain for industry and regulators. These challenges include "an evolving regulatory environment; biophysical and socio-economic knowledge gaps; the impacts of climate change; and lack of infrastructure.”211

According to a 2004 report of the Canadian Centre for Energy Information (CCEI), "Nunavut has been estimated to contain as much as 10 per cent of Canada's conventional crude oil resources and nearly one-quarter of our natural gas resources." 212 The development of Arctic petroleum resources has been dormant for many years due to high costs, a complex regulatory environment, Aboriginal issues, short seasons, and environmental issues involved in building production and transportation systems to distant markets. Since 1985, the landscape with respect to Aboriginal rights has changed and now any development in Nunavut will be subject to the NLCA and the NBRLUP.

On 8 April 2010, a story from the Nunavut News entitled, “Ottawa to hunt for oil in Nunavut's Lancaster Sound — Geological Survey project goes forward despite marine park

Beaufort Sea Strategic Regional Plan of Action: Interim Draft (March 2007) at 3, online: Beaufort Sea Strategic Regional Plan of Action <http://www.bsstrpa.ca/uploads/RPA\%20Interim\%20Draft\%20 Feb.28.doc > [Regional Plan of Action]. Implemented by the Canada-Yukon Oil and Gas Implementation Act, S.C. 1998, c. 5. Si Brown, Environmental Impacts of Arctic Oil and Gas Development (London: University of Western Ontario, 1975).

Online: Environmental Studies Research Funds <http://www.esrfunds.org/index_e.php>.

Regional Plan of Action, supra note 207 at 3.

CCEI, Canada's Offshore Oil and Gas Industry (Calgary: CCEI, 2004) at 3, online: British Columbia Energy, Mines and Petroleum Resources <http://www.em.gov.bc.ca/DL/offshore/Reports/Offshore FAMar2004_low.pdf $>$. 
declaration," raised some controversy over offshore oil and gas development. ${ }^{213}$ At the same time that the federal government was hailing Lancaster Sound as a recent example of the Conservative Government's commitment to conservation, federal officials from the Geological Survey of Canada, a division of Natural Resources Canada, were seeking approval for a research expedition, in the summer of 2010, to board a German icebreaker, the Polarstern, and study the petroleum potential of Lancaster Sound. Given all of the other factors at play in the north and the decrease in the availability of hydrocarbons, offshore oil and gas development in Nunavut may have a rebirth.

\section{F. DeVelopments in Aboriginal Title to SEA Spaces}

In Canada today, there are a number of settled land claim agreements that expressly extinguish Aboriginal claims to sea spaces. ${ }^{214}$ Section 3(4) of the IFA conveys to the Crown, "all ... aboriginal claims, rights, title and interests ... in and to the Northwest Territories and Yukon Territory and adjacent offshore areas" and art. 15.2.3 of the NLCA states that, "[t]here shall be no Inuit Owned Land in marine areas.”215

There is one agreement, however, that does recognize Aboriginal title to sea spaces, although it does come with a qualification. Chapter 4 of the Labrador Inuit Land Claims Agreement provides the Inuit with special rights in approximately 28,000 square miles of land and 18,800 square miles of tidal waters located within Canada's 12-mile territorial sea. ${ }^{216}$ Also included are a number of water lots that extend out under the ocean, with an area of approximately 22.25 square miles, that have been included in the defined "Labrador Inuit Lands." Section 4.4.3 of the LILCA provides that the Inuit estate in Labrador Inuit Lands under s. 4.4.1 extends to:

(a) the sea bed within the boundaries of Water Lots set out in the Map Atlas (shown for illustrative purposes only in schedule 4-D) and described in appendix A-3 Part 4, but does not include ownership of Tidal Waters above the sea bed within the boundaries of the Water Lots; and

(b) all lands covered by Water that are within the boundaries of Labrador Inuit Lands, but does not include ownership of Water. $^{217}$

Noteworthy when discussing Aboriginal title in Canada is the Supreme Court decision of Delgamuukw v. British Columbia. ${ }^{218}$ Delgamuukw is the seminal case in Canada regarding claims of Aboriginal title. The principles set out in Delgamuukw deal with Aboriginal title to land, not sea spaces. There have been arguments that there is no reason why those same

Randy Boswell, “Ottawa to hunt for oil in Nunavut's Lancaster Sound” Nunatsiaq Online (8 April 2010), online: Nunatsiaq Online <http://www.nunatsiaqonline.ca/stories/article/98789_ottawa_to_ hunt_for_oil_in_nunavuts_lancaster_sound/>. C. Rebecca Brown \& James I. Reynolds, “Aboriginal Title to Sea Spaces: A Comparative Study” (2004) 37 U.B.C. L. Rev. 449 at 463.

215 Ibid.

216 Land Claims Agreement Between the Inuit of Labrador and Her Majesty the Queen in Right of Newfoundland and Labrador and Her Majesty the Queen in Right of Canada (22 January 2005), online: Indian and Northern Affairs Canada <http://www.ainc-inac.gc.ca/al/ldc/ccl/fagr/labi/labi-eng.pdf> [LILCA]. For settlement legislation see the Labrador Inuit Land Claims Agreement Act, S.C. 2005, c. 27.

218 [1997] 3 S.C.R. $1010[$ Delgamuukw]. 
principles could not be applied to sea spaces, however, it has not yet been considered. Academics claim that difficulty will likely arise in meeting one of the requirements of the test in Delgamuukw to prove title, this being sufficient evidence of exclusive occupation at the time of British or Canadian sovereignty. ${ }^{219}$

It is difficult to know whether arguments concerning Aboriginal title to sea spaces may find favour in Canada. There are, however, such types of developments in Aboriginal title to sea spaces being argued in other parts of the world. If title to water was recognized, this could have a considerable impact on the consultation duty of the Crown and the oil and gas industry. It is unlikely that the federal government would lose control over the jurisdiction and regulation of the offshore, but not as difficult to imagine the possibility of Aboriginal governments gaining control over the inland waters and sea beds. Existing agreements would have to be amended to recognize the broadened rights and the duty to consult would become more stringent given increased marine traffic, potential for economic development, and conservation issues.

Developments in Aboriginal title to sea spaces in Alaska, Australia, and New Zealand are worthy of review here since they may affect the Canadian legal landscape.

\section{UNITED STATES - AlasKA}

Before Alaska became a state there was some recognition that Aboriginal peoples may have claim to sea spaces by virtue of the U.S. Supreme Court's decision that Congress had the authority to create a reservation that included adjacent waters and submerged lands, as well as the upland. ${ }^{220}$ However, since Alaska has become a state, the law has taken a different course as is evident in Inupiat Community of Arctic Slope v. United States, ${ }^{221}$ where the Inupiat People tried to claim rights to an area lying three to 65 miles offshore in the Beaufort and Chukchi Seas. The Inupiat claimed that they had valid Aboriginal title to the area, including the exclusive use and occupancy of the adjacent sea from time before human memory. Based on this contention, the Inupiat claimed that this established their rights to the surface of the sea, the water column beneath it, the seabed, and the minerals laying beneath the seabed. Not only did the Inupiat seek an injunction to prevent the U.S. government and oil companies from interfering with their rights, they sought damages and a declaration of their title to, and control over, the area.

The claim of the Inupiat was rejected on the basis of the U.S. Supreme Court's previous holding that the U.S. government had paramount rights in the sea waters lying seaward of the ordinary low-water mark. ${ }^{222}$ This claim of federal paramountcy is also found in Canadian cases where Aboriginal groups have attempted to establish Aboriginal title. There is, however, one significant difference from the Alaskan arguments, which is that in Canada the Oceans Act provides protection of Aboriginal or treaty rights. The Oceans Act states:

Brown \& Reynolds, supra note 214 at 492.

Alaska Pacific Fisheries v. United States, 248 U.S. 78 (1918).

548 F. Supp. 182 (D. Alaska 1982), aff'd 746 F.2d 570 (9th Cir. 1984), cert. denied 474 U.S. 820 (1985).

Ibid. at 187. 
For greater certainty, nothing in this Act shall be construed as to abrogate or derogate from any existing aboriginal or treaty rights of the aboriginal peoples of Canada under section 35 of the Constitution Act, $1982^{223}$

The above section must be seen as making the Oceans Act subject to Aboriginal or treaty rights. Section 8 of the Oceans Act vests in Canada title to the seabed and subsoil below the internal waters of Canada and the territorial sea of Canada. ${ }^{224}$

\section{AUSTRALIA}

The seminal case of the High Court of Australia is the Commonwealth v. Yarmirr, ${ }^{225}$ where the Court had to decide the claim of Aboriginal peoples to exclusive rights and interests to the sea and the seabed in Northern Australia. The issue on appeal in Yarmirr was the recognition by the common law of Aboriginal rights and interests in the seabed. The Court's discussion of these rights included common law principles similar to those found in the Canadian common law. These principles include the territorial reach of the common law, the requirement that in order to find Aboriginal title there is a need for a radical title in the Crown and, finally, the relevance of Crown assertion of sovereignty over areas beyond the low-water mark.

In considering of these issues, the High Court of Australia held that "the common law will recognise rights and interests which are of the kind the subject of the determination in this matter and it will do so by affording remedies for their enforcement and protection." ${ }^{226}$ It is not idle to consider that a Canadian court might reach a similar decision upon review of the relevant common law principles. The burden of proof for the Aboriginal group would be to establish that title or rights pre-existed with respect to a certain area of sea space.

\section{NEW ZEALAND}

New Zealand has always recognized the common law principle of Aboriginal title and therefore much of its jurisprudence is based on legislation. One of the major differences between New Zealand common law and Canadian common law is that there is no provision in New Zealand common law to consider the possible extinguishment of Aboriginal rights. In New Zealand, Aboriginal title is based on customary values and practices at the time of the claim and not, as in Canada, at the time of British sovereignty. As a result, New Zealand's Aboriginal jurisprudence is of interest to Canada's Aboriginal law. ${ }^{227}$ Currently there is no New Zealand case law involving Aboriginal claims to sea spaces.

Supra note 12, s. 2.1 .

Ibid.

[2001] HCA 56, 208 C.L.R. 1 [Yarmirr].

Ibid. at para. 76 .

See e.g. R. v. Symonds, [1847] N.Z.P.C.C. 387; Nireaha Tamaki v. Baker, [1901] N.Z.P.C.C. 371. 


\section{IMPLICATIONS OF INTERNATIONAL VIEWS ON ABORIGINAL TITLE TO SEA SPACES}

In considering the effect of the foregoing jurisprudence, it is noteworthy that some writers have concluded that the outcomes of these title claims are dependent upon local customary law rather than broad common law principles. As put by one writer:

[C]are must be exercised in the use of judicial authorities of other former colonies and territories of the Crown because of the peculiarities which exist in each of them arising out of historical and constitutional developments, the organisation of the indigenous peoples concerned and applicable geographical or social considerations

The ways in which each of the former colonies and territories of the Crown addressed the reconciliation between native title and the legal doctrine of tenure sustaining estates in land varied so markedly from one former territory to the other and were affected so profoundly by local considerations (legal and otherwise) that is virtually impossible to derive applicable common themes of legal principle. $^{228}$

The United Nations Declaration on the Rights of Indigenous Peoples, ${ }^{229}$ ratified by the UN General Assembly in 2006, is also noteworthy. The consultation provisions are quite broad and while Canada has not yet ratified it, ratification would have the potential to significantly affect the duty to consult and accommodate doctrine that we know today in Canada. The consultation provisions state:

\section{Article 19}

States shall consult and cooperate in good faith with the indigenous peoples concerned through their own representative institutions in order to obtain their free, prior and informed consent before adopting and implementing legislative or administrative measures that may affect them.

Article 32(2)

States shall consult and cooperate in good faith with the indigenous peoples concerned through their own representative institutions in order to obtain their free and informed consent prior to the approval of any project affecting their lands or territories and other resources, particularly in connection with the development, utilization or exploitation of mineral, water or other resources. ${ }^{230}$

Fejo v. Northern Territory, [1998] HCA 58, 195 C.L.R. 96 at paras. 101, 103 [footnotes omitted]. GA Res. 61/295, UNGAOR, 61st Sess., Supp. No. 49, UN Doc. A/61/49 (2008) 15, online: United Nations Permanent Forum on Indigenous Issues <http://www.un.org/esa/socdev/unpfii/documents/ DRIPS_en.pdf $>$. Ibid. 


\title{
VIII. CONCLUSION
}

The Arctic is very complex. It has many levels of regulation and persuasion. The WWF papers on Governance and Regulation of the Arctic conclude that substantial reform of the international regime in the Arctic is urgently required. As the report states:

\begin{abstract}
It is submitted that the need for reform as such is not disputed. There is no scientific disagreement that the Arctic is rapidly changing. Rather, the debate focuses on the pace of change and future projections. The governance and regulatory regime that currently exists in the Arctic may have been adequate for an environment that largely restricted human activity for most of the year. But when the Arctic Ocean becomes increasingly similar to regional seas in other parts of the world for ever longer parts of the year, adequacy can no longer be assumed. ${ }^{231}$
\end{abstract}

International co-operation is laudatory. This co-operation, very productive of "guidelines," does not quickly lead to enforceable rules. One of the most salient points of the WWF study is that there is very little in the Arctic beyond guidelines. The reason why we have paid so much attention in this paper to the great number of consensual arrangements is that they tend to be the starting place for eventual domestic laws. The discussion of marine-protected areas is but one of many examples.

The slow pace of the development of domestic laws resulting from international cooperation can, however, change very quickly. Change to the rapid enactment of laws tends to occur as a result of unforeseen and usually unfortunate events. The Titanic gave rise to the SOLAS Convention and its many rules concerning the safety of ships at sea. The sinking of the Ocean Ranger off the coast of Newfoundland in 1982 produced many changes in regulation of the offshore industry, and also in the design and construction of offshore drilling units. The Deepwater Horizon incident has the potential to produce many changes to offshore exploration. It is doubtful whether the NEB review of offshore drilling in the Arctic would be happening were it not for the Deepwater Horizon. Most importantly, that review serves to highlight the many agendas that are relevant for consideration in the Arctic.

Now more than ever it is necessary to consider the broad view when thinking about the Arctic. Charles Emmerson in The Future History of the Arctic, ${ }^{232}$ after a very interesting and thorough review of the past, present, and potential future of the Arctic suggests that the future Arctic may be

a zone of global cooperation, a focus for scientific research and global environmental stewardship. More likely, however, is the image of the Arctic as a battleground, fought over not just by states but by the different economic and political interests that are jostling for their part of the Arctic future, trying either to develop its economic potential or to protect its environment. A battleground does not mean war, but it does mean conflict and competition: political, economic, cultural, and diplomatic.

There is no fatality to such a conclusion - though history and current events support it. The institutions of global governance will likely avert some potential for conflict or channel it into bureaucratic resolution. 
Economic and environmental groups may yet achieve the kind of cooperative approach that would put their objectives in balance, rather than in more confrontational opposition to one another. Arctic countries could find a way of articulating a common vision of the Arctic's future and cooperating to achieve it. Perhaps. But as the Arctic enters the course of global history and its uniqueness is taken from it, the likelihood of the Arctic escaping the realpolitik of the rest of the world seems low. We no longer deal with the Arctic as we would wish it to be - in the future, we will have to deal with the Arctic as it is. ${ }^{233}$

The continued development of the offshore oil and gas industry in the Canadian Arctic will take place in this rapidly changing environment. 